\title{
A condição evangélica da Globalização e a estratégia político-espacial da universal do reino de Deus
}

\author{
THE EVANGELICAL CONDITION OF GLOBALIZATION AND THE POLITICAL-SPATIAL STRATEGY OF THE UNIVERSAL DO \\ REINO DE DEUS
}

\section{RESUMO}

O objetivo deste texto é refletir sobre a expressão do pentecostalismo protestante a partir do Brasil. Tem-se como hipótese que o pentecostalismo é uma manifestação social americana, associada às qualidades espaciais da atual globalização, condicionada pela urbanização generalizada. Uma globalização que foi se intensificando no final do século XX, a partir da América e do seu modelo capitalista. Sustentado na hiperprodução de necessidades e mercadorias que transbordam o consumo, esse modelo americano dilatou a urbanização por todos os lados e difundiu valores e comportamentos empreendedores de forma surpreendente, principalmente pela imposição da desregulamentação da economia e do trabalho. Organizado em três partes, este artigo inicialmente apresenta algumas referências conceituais sobre a atual globalização associando-a à urbanização. Em seguida, são apresentados dados sobre o urbano na atualidade para localizar o Brasil nesse contexto. A terceira parte é dedicada ao protestantismo pentecostal, sobretudo ao estudo da dinâmica espacial de uma de suas ramificações, a igreja neopentecostal Universal do Reino de Deus, uma criação eminentemente brasileira que, nascida do subúrbio carioca, em 1977, se estendeu para o mundo. Misturando fé e política e associando formas e estratégias de difusão tradicionais e modernas, a Universal é um excelente exemplo dessas novas manifestações sociais da globalização aos moldes americanos.

Palavras-chave: Evangélicos pentecostais. Globalização. Urbanização generalizada. Estratégia político-espacial. Igreja Universal do Reino de Deus.

\section{ABSTRACT}

The purpose of this text is to reflect on the expression of Pentecostal Evangelical from Brazil. It is hypothesized that Pentecostalism is an American social manifestation, associated with the spatial qualities of the current globalization, which the generalized urbanization of society is its condition. A globalization that has been intensified since the end of the 20th century, starting with America and its capitalist model. Sustained by the hyper production of needs and goods that overflows consumption, this American model expanded urbanization everywhere and spread entrepreneurial values and behaviors in a surprising way, mainly due to the imposition of deregulation of the economy and of work. Organized in three parts, this article begins by presenting some conceptual references on the current globalization and its association with urbanization. Then, data about the urban today are brought here to locate Brazil in this context. The third part is dedicated to Pentecostal Evangelical, especially to the study of the spatial dynamics of one of its branches, the Universal neo-Pentecostal church of the Kingdom of God: an eminently Brazilian creation, which was born in the Rio de Janeiro suburb, in 1977, extended to the world. Mixing faith and politics and associating traditional and modern forms and strategies of diffusion, Universal is an excellent example of these new social manifestations of globalization along American lines.

Keywords: Pentecostal evangelicals. Globalization. Widespread urbanization. Political-spatial strategy. Igreja Universal do Reino de Deus.

\author{
Mônica Sampaio Machado a \\ (D) Gustavo Luiz Xavier de Abreu a \\ ${ }^{a}$ Universidade do Estado do Rio de \\ Janeiro (UERJ), Rio de Janeiro, RJ, Brasil
}

DOI: 10.12957/geouerj.2020.56895

Correspondência:

monicasampaiomachado@gmail.com

Recebido em: 17 abr. 2020

Aceito em: $21 \mathrm{dez} .2020$ 


\section{INTRODUÇÃO}

Podemos dizer que, desde finais da década de 1960, um novo modelo capitalista se instaurou no mundo, o modelo americano. Esse capitalismo aos moldes americanos tornou-se cada vez mais sistêmico e planetário, passando a estar diretamente movido pelo imperativo do mercado global, criando novas formas dominantes de produção e consumo, assim como de comportamentos e expressões políticas, religiosas e culturais de alcance mundial. A urbanização generalizada tornou-se sua expressão espacial. Essa nova etapa que foi denominada de globalização, discutida tanto no mundo acadêmico quanto no cotidiano, parece que nada mais é do que uma americanização do mundo. ${ }^{1}$

Essa americanização, embora tenha tido seu centro difusor na nação norte-americana, representa uma forma e um sentido continental de agir, do continente americano como totalidade. Diferente do modo operante europeu, no capitalismo ao molde americano a produção não mais atende ao consumo, e sim vem à sua frente e o transborda, promovendo incessantemente novas necessidades, dentre as quais os serviços e o crédito generalizado desempenham importância singular. As condições não apenas culturais da América, mas sobretudo geográficas, como grandes espaços territoriais unificados, parecem ter participação fundamental na construção desse novo capitalismo.

Essa globalização americanizada foi possibilitada pela ampliação dos capitais fixos e constantes e, consequentemente, pelo aumento e importância dos fluxos, sobretudo na última década do século XX. Assim, o espaço geográfico se modificou enormemente com a construção e ampliação de estradas, portos, aeroportos, pontes, prédios, casas, fábricas, etc. Foram igualmente criadas novas formas de produção, abastecimento de energia e cidades, assim como uma variedade de mercadorias, tais como cabos de telecomunicação e dados, carros, veículos em geral, sementes híbridas, inúmeros eletrodomésticos, smartphones, computadores, vestuários, móveis, etc. Tudo em excesso. Criaram-se, nesse sentido, novas paisagens, envolvidas diretamente por objetos produzidos pela indústria e pela tecnologia, mas agora sob o comando das demandas da "sociedade urbana", uma sociedade extremamente consumista e predominantemente capitalista, um capitalismo com características diferentes do que predominou no século $X X$, bastante evidente no continente americano, mas também de expressão na África e Ásia.

A efetivação dessa nova sociedade, desse novo capitalismo, foi sendo possibilitada pela ampliação e diversificação do setor terciário. Em todas as áreas, econômica, política e cultural, a produção passou a estar à frente do consumo. 0 cartão de crédito, por exemplo, foi uma invenção norte-americana, justamente para

\footnotetext{
1 A concepção aqui defendida da globalização como "americanização do mundo" é de autoria de André Martin, professor da Universidade de São Paulo. Com posições ideológicas e com argumentações diferenciadas, Pedro Geiger também defende e fortalece a mesma associação. Assim, embora nos responsabilizando totalmente pelas afirmações apresentadas neste trabalho, não podíamos deixar de mencionar tais influências.
} 
potencializar o consumo. A compra passou a ser realizada sem dinheiro. Intensificaram-se o crédito, a propaganda, a publicidade e os serviços de diversas naturezas, todos sustentados, principalmente, na internet, no sistema global de rede de computadores. $O$ transbordamento da produção para além do consumo que caracterizou esse novo modelo capitalista, embora tenha tido suas origens nos Estados Unidos, é evidenciado na maior parte da América, sobretudo no Brasil, ou seja, metade do continente sul-americano. Tanto os Estados Unidos quanto o Brasil possuem grandes espaços territoriais unificados; um sistema urbano amplo que se expande reforçando a urbanização; cidades gestoras desse sistema (no caso brasileiro São Paulo, Rio de Janeiro e Brasília); um expressivo mercado consumidor; uma população com forte tendência consumista, favorecida justamente pela dinâmica do crédito; e uma dinâmica social muito menos rígida do que no caso europeu.

Assim, essa urbanização generalizada instaurou um novo espaço geográfico, que, além de modificar seu conteúdo material, dado agora pela simbiose entre modernas técnicas e entes geográficos, modificou igualmente as formas e as organizações das relações sociais. Portanto, esse extenso e recente processo de urbanização foi estabelecido tanto pelo reino das técnicas modernas, que agregaram fortemente a tríade ciência-tecnologiainformação ao território, quanto por uma nova atmosfera psíquica, comportamental e de valores a ele associada. Esse novo meio é o meio técnico-científico-informacional desenvolvido por Milton Santos, construído pelo ambiente material da técnica, a tecnosfera, e o ambiente subjetivo a ela associado, a psicosfera.

Organizado em três partes, este artigo inicialmente apresenta algumas referências conceituais sobre a atual globalização associada à urbanização. Em seguida, são apresentados dados sobre o urbano na atualidade para localizar o Brasil nesse contexto. A terceira parte é dedicada ao estudo da dinâmica espacial de uma ramificação protestante pentecostal, a Igreja Universal do Reino de Deus, uma criação eminentemente brasileira que, nascida do subúrbio carioca, em 1977, se estendeu para o mundo. Misturando formas e estratégias de difusão tradicionais e modernas, a Universal é um excelente exemplo de novas expressões sociais da globalização aos moldes americanos.

\section{A expressão espacial da globalização, a urbanização generalizada da sociedade}

Em finais da década de 1960, um dos maiores teóricos marxistas, Henri Lefebvre, já apontava que a crise mais importante e central da sociedade contemporânea era a crise da realidade urbana (LEFEBVRE, 1999). Desde então, Lefebvre defendia a ideia de que a sociedade vivia uma nova etapa da história humana, a etapa urbana. Esta havia sido produzida pelo recrudescimento da "sociedade urbana" por todo o planeta, pelo domínio da urbanização, a urbanização completa e generalizada da sociedade. Para o filósofo, entretanto, naquele momento tratava-se ainda de uma realidade virtual, que no futuro viria a se tornar real. ${ }^{2}$

\footnotetext{
2 "Partimos de uma hipótese: a urbanização completa da sociedade. [...]. Esta hipótese implica uma definição. Denominaremos 'sociedade urbana', a sociedade que resulta da urbanização completa, hoje virtual, amanhã real”. (LEFEBVRE, 1999, p. 15). É
} 
Lefebvre estava correto no prognóstico. Para melhor entender essa predição e sua força explicativa na atualidade, vale a pena explorar o significado de "sociedade urbana", dado pelo autor para definir a sociedade contemporânea e delimitar a natureza da crise que ela atravessa. O termo "sociedade urbana" é por ele empregado para caracterizar uma sociedade específica, historicamente datada, que nasce da industrialização, do processo que domina e absorve a produção agrícola. Produto do desenvolvimento histórico, entendido por Lefebvre como modelo de sequência dialética, da urbanização completa e da concretização da industrialização, a sociedade urbana é definida pela sucessão emaranhada de três camadas, épocas ou campos: rural, industrial e urbano. Cada campo, camada ou etapa corresponde a formas específicas de autoritarismo, de reformismo e de revolução.

\begin{abstract}
No primeiro campo, na esfera da agricultura, floresceram a família, a sociedade patriarcais [...]. No que concerne ao período da industrialização, ele fez nascer um paternalismo do chefe de empresa (patrão). 0 que aconteceu é a superposição e consolidação do patriarcalismo (camponês) e do paternalismo (industrial) para engendrar a figura do Chefe de Estado perfeito [...]. A industrialização tendo exigências muito fortes [...], leva a conseqüências políticas contraditórias: revoluções e autoritarismo [...].

Os sintomas da passagem ao período urbano já se manifestam com força. Um paternalismo urbano, ainda velado pelas figuras das idades precedentes, causa danos; os "notáveis" urbanos que exerceram a autoridade ornamentam-se com o duplo prestígio do Pai e do Capitão de indústria. A reforma urbana que resgataria o solo das servidões devidas à propriedade privada (por conseguinte da especulação) já tem alcance revolucionário. Continentes inteiros passam das formas anteriores de ação revolucionária à guerrilha urbana, aos objetivos políticos concernentes à vida e à organização urbanas (sem poder omitir nem resolver, por isso, os problemas da organização industrial e da agricultura se superpõem). Começa o período das revoluções urbanas.

Assim se confirma a concepção, no tempo histórico, dos três campos sucessivos. Pode-se acrescentar que o mais novo, o que emerge, age simultaneamente como catalisador e analisador do campo, ou melhor, dos campos preexistentes (o agrário e o industrial). (LEFBVRE, 1999, p. 49-50).
\end{abstract}

É interessante notar que Lefebvre não interpreta a história da humanidade como uma simples e evolutiva sucessão de etapas. Sua concepção dialética enxerga o presente não como um rompimento, um corte radical com o passado, mas como um novo conjunto onde se misturam e se relacionam dinâmicas passadas e presentes. Seguindo esse raciocínio, isso significa afirmar que a sociedade contemporânea é constituída tanto de elementos e camadas de um passado, próximo ou longínquo, quanto do presente, em constantes e diversas associações. Concepção que parece igualmente muito interessante para pensar e planejar o futuro da sociedade, enxergandoo não como algo irrealizável, mas como possível. Esses conceitos permitem também um olhar mais atento ao estudo espacial, abrindo novas possibilidades para análise e entendimento de lugares tão diversos do mundo contemporâneo, enxergando-os como portadores de normas, formas e bens materiais e imateriais do passado e do presente em constantes associações, que condicionam o futuro.

Igualmente importante é perceber que no modelo interpretativo do desenvolvimento histórico em três camadas ou etapas de Lefebvre estão duas fases críticas que ao final apontam para a supremacia do urbano: a da subordinação à indústria e a da subordinação da indústria à urbanização, que por sua vez dá o sentido à urbanização. A cidade política da primeira fase cede, então, lugar à cidade mercantil, que por sua vez é varrida pelo 
movimento da industrialização, negador da cidade. Contudo, ao final do processo a urbanização generalizada promovida pela indústria reconstitui a cidade em um nível superior; é assim que o urbano ultrapassa a cidade que o contém em origem, mas que agora se torna causa e indutor da industrialização e da própria cidade. Afirma-se, assim, o terceiro e atual estágio da história humana, isto é, a supremacia do urbano no mundo e, consequentemente, a "crise urbana" no mundo.

É esta conjuntura que dá um sentido à expressão "revolução urbana", concebida como conjunto das transformações que atravessa a sociedade contemporânea, para passar do período onde predominam as questões de crescimento e a industrialização ao período onde a problemática urbana prevalecerá decisivamente, onde a busca das soluções e das modalidades próprias à sociedade urbana passará ao primeiro plano. (LEFEBVRE apud CASTELLS, 1983, p. 115).

Como os três campos indicam estágios diferenciados de desenvolvimento da história humana, mesmo guardando elementos do passado, cada um deles irá expressar características próprias, ou seja, específicas formas espaciais, técnicas de agricultura e indústria, assim como modos de pensamento, de ação e de vida. No caso do terceiro campo, a "sociedade urbana", em função do espraiamento e extensão do fenômeno urbano no mundo contemporâneo, da expansão do processo de urbanização, verifica-se grande sintonia, associação e semelhança entre formas de pensamentos e práticas sociais nas diversas porções do planeta. Tal condição foi dada e construída pela consolidação do mercado global e da sociedade global, que por sua vez se sustentou na difusão e desenvolvimento da industrialização e das técnicas no espaço.

A chamada era da globalização pode, então, ser associada ao "terceiro campo", ao terceiro estágio de desenvolvimento defendido por Lefebvre, ao da "sociedade urbana". Estágio caracterizado por um amplo processo de expansão dos objetos técnicos em todo o planeta, sempre acompanhado por introduções de novos comportamentos econômicos, políticos e culturais, um amplo processo de urbanização. Desse modo, é possível afirmar que o "terceiro campo" é definido pela urbanização generalizada, isto é, a urbanização completa da sociedade. É esse o sentido dado por Lefebvre quando o denomina de "sociedade urbana", aqui entendida como a expressão mais evidente da globalização, o modo espacial de realização da globalização. A urbanização, entretanto, pôde se verificar não apenas pelo desenvolvimento, difusão e materialização da técnica no território, mas sobretudo por sua unicidade, condição que permitiu o diálogo dos objetos técnicos e a interação dos lugares e territórios. Todo esse quadro, por sua vez, foi construído e impulsionado ao longo do processo industrial, que na atualidade está orientado pelas demandas da globalização, portanto, da urbanização. As contribuições de Milton Santos sobre globalização ajudam a desenvolver essa associação (industrialização, globalização e urbanização) e serão brevemente apontadas a seguir.

Na segunda metade da década de 1980, Milton Santos escreveu um pequeno livro intitulado Metamorfoses do espaço habitado, com primeira edição em 1988, onde apresentava e discutia o significado de globalização e sua expressão espacial. Posteriormente, em 1992, em parceria com Maria Adélia de Souza, participou da organização 
do Encontro Internacional "O Novo Mapa do Mundo", realizado na USP, e publicou três livros como produto deste evento, um deles denominado $O$ novo mapa do mundo: fim de século e globalização (SANTOS, et al., 1993a). Tratava-se de uma coletânea de artigos que apresentava não apenas a preocupação do autor em discutir o conceito de globalização, mas também de diversos profissionais que debatiam os novos mapas políticos, as novas expressões da cultura e da técnica, a nova dinâmica econômica e o então processo de metropolização. Em 1993, Milton Santos publica $A$ urbanização brasileira (SANTOS, 1993b), associando o que denominava de fase atual, o meio técnico-científico, à remodelação do território brasileiro, à urbanização brasileira. Em 1994, dando continuidade a essa reflexão, o autor lança Técnica, espaço, tempo: globalização e meio técnico-científicoinformacional. Embora a informação já aparecesse em suas primeiras obras como condição essencial da nova etapa da história humana, aqui passa a fazer parte da denominação dada a esse novo meio, o meio técnico-científicoinformacional. Em 1996, publica A natureza do espaço: técnica e tempo, razão e emoção, apresentando sua síntese teórica sobre globalização e espaço geográfico, síntese esta que pode ser encontrada em germe no livro Metamorfoses do espaço habitado (SANTOS, 1988).

Essas obras dão sequência ao pensamento do Milton Santos e têm em comum a reflexão da globalização a partir da geografia material, ou seja, uma análise da expressão espacial da globalização. Ao destacar a importância, o alcance e o domínio da técnica e informação na sociedade contemporânea, o autor percebe e denuncia o vazio que existe sobre este debate a partir da ótica espacial. É nesse sentido que ele elabora um importante referencial conceitual, que no presente artigo surge como chave interpretativa da "sociedade urbana", da expressão espacial da 'globalização', o conceito de meio técnico-científico-informacional, no qual associa técnica, espaço, sociedade, tempo e informação.

Para o autor o meio técnico-científico-informacional é também produto do desenvolvimento histórico da humanidade, efetivado principalmente com a expansão da industrialização. Assim como Lefebvre, Milton Santos defende que este seria o terceiro estágio de desenvolvimento - o primeiro é o meio natural; o segundo, o meiotécnico; e o terceiro, o meio técnico-científico-informacional. Conforme o autor, este terceiro período começa após a Segunda Guerra Mundial e sua afirmação vai ocorrer, inclusive nos países pobres, na década de 1970. Este período distingue-se dos outros pela profunda interação da ciência e da técnica, que irá se verificar sob a proteção do mercado, que, por sua vez, graças à ciência e à técnica, se torna um mercado global. Nesse período, os objetos técnicos tendem a ser ao mesmo tempo técnicos e informacionais, indicando que a energia principal de seu funcionamento é também informação.

Da mesma forma como participam da criação de novos processos vitais [...], a ciência e a tecnologia, junto com a informação, estão na própria base da produção, da utilização e do funcionamento do espaço e tendem a constituir o seu substrato.

Antes eram apenas as grandes cidades que se apresentavam como o império da técnica, objeto de modificações, supressões, acréscimos, cada vez mais sofisticados e carregados de artifício. Esse mundo artificial inclui, hoje, o mundo rural. (SANTOS, 1996, p. 190). 
Assim, a chamada urbanização do campo, atualmente bastante discutida entre os geógrafos que se dedicam à temática agrária, pode ser entendida como a expansão do meio técnico-científico-informacional, uma paisagem agora cada vez mais composta por objetos técnicos e informacionais. Os espaços se requalificam, sobretudo, para atender às demandas do mercado mundial. Conforme Milton Santos (1996, p. 191), "esse novo meio técnicocientífico-informacional é a cara da globalização. (...). Mesmo onde se manifesta pontualmente, ele assegura o funcionamento dos processos encadeados a que se está chamando de globalização".

A urbanização do campo significa, desse modo, o processo de mudanças tanto das relações sociais quanto do conteúdo material do território, dado agora pela técnica como extensão e universo dos meios geográficos. A revolução urbana como forma de criar uma segunda natureza se junta a essa revolução técnico-agrícola do mundo atual. O resultado é a visão do mundo como uma metrópole total (SANTOS, 1996, p. 190-203). Modificam-se a qualidade e a quantidade da população e dos empregos, dos capitais utilizados, das formas de organização e das relações sociais (SANTOS, 1996, p. 191).

\section{A tecnosfera e a psicosfera na globalização}

Esse processo de urbanização do mundo, o mundo como metrópole total, produz o que Milton Santos chamou de tecnosfera, um amplo reino da técnica. É consolidado em todo o planeta um amplo e novo ambiente, funcionando de forma sistêmica, cada vez mais permeado e orientado pela técnica, que agora constitui também, ao lado da montanha, do mar, da planície, do deserto, etc., a geografia dos lugares. Esse novo ambiente produz, ainda, uma nova atmosfera psíquica e comportamental, uma nova psicosfera, isto é, um conjunto de novos pensamentos, comportamentos, ideias, crenças, sentidos e paixões associados.

\footnotetext{
A tecnosfera se adapta aos mandamentos da produção e do intercâmbio e, desse modo, frequentemente traduz interesses distantes; desde, porém, que se instala, substituindo o meio natural ou meio técnico que o precedeu, constitui um dado local, aderindo ao lugar como uma prótese. A psicosfera [...] também faz parte desse meio ambiente, desse entorno da vida fornecendo regras à racionalidade ou estimulando o imaginário. Ambas, psicosfera e tecnosfera, são locais, mas constituem o produto de uma sociedade bem mais ampla que o lugar. Sua inspiração e suas leis têm dimensões mais amplas e complexas.

Tecnosfera e psicosfera são redutíveis uma à outra. O meio geográfico atual, graças ao seu conteúdo em técnica e ciência, condiciona os novos comportamentos, e estes, por sua vez, aceleram a necessidade da utilização de recursos técnicos, que constituem a base operacional de novos automatismos sociais. Tecnosfera e psicosfera são os dois pilares com os quais o meio técnico-científico introduz a racionalidade, a irracionalidade e a contra-racionalidade, no próprio conteúdo do território. (SANTOS, 1996, p. 204).
}

Em todo o mundo, assim, consolidam-se cada vez mais novos ambientes, dados pela implantação constante de objetos técnicos com alta carga de ciência e informação. Esses objetos agora estão acoplados ao território, formando prolongamentos do território, o que Milton Santos (1996) denomina de verdadeiras próteses. Esse novo ambiente é acompanhado também por mudanças de mentalidades e comportamentos, constituindo a já mencionada esfera psicológica, a psicosfera, que apoia, acompanha e, por vezes, antecede a expansão do meio técnico-científico-informacional (RIBEIRO, 1991, p. 44-55). 
Essa psicosfera produz a busca social da técnica e a adequação comportamental à interação moderna entre tecnologia e valores sociais. Alguns setores produtivos parecem alimentar, com especial ênfase, os processos culturais de consolidação dessa psicosfera, conformando verdadeiros pólos emissores de valores. (RIBEIRO, 1991, p. 48).

Novas formas de expressão cultural e novos valores surgem com grande força no Brasil urbano e ultrapassam as fronteiras nacionais, possibilitados justamente pela tecnosfera e a esfera psicológica a ela associada, a psicosfera. O exemplo trazido é o da dinâmica da Igreja Universal do Reino de Deus, aqui considerada como característica do capitalismo atual aos moldes americanos. De matriz essencialmente brasileira, essa igreja tem se difundido com grande sucesso, tanto pela força de sua oratória religiosa quanto pelas estratégias territorial e política adotadas. Contudo, antes de explorar a dinâmica da Universal, alguns dados sobre a urbanização do mundo serão agora apresentados, com o intuito de localizar o Brasil nesse contexto e refletir sobre especificidades de suas manifestações sociais na globalização atual.

\section{Um panorama da urbanização em tempos de globalização e o caso brasileiro}

Em 200 anos a população mundial se multiplicou por mais de seis, passando de 1 bilhão de pessoas, em 1800, para 6,1 bilhões, em 2000. Entretanto é apenas na década de 1930 que a população dobrou de tamanho e ganhou seu segundo bilhão, e em 1960, seu terceiro. De lá para cá o crescimento populacional tem sido muito rápido e expressivo: em 1975 chega a quatro bilhões; em 1987, a cinco, e em 1999, a seis. Assim, em apenas 40 anos a população mundial passaria de 3 bilhões, em 1960, para mais de 6,1 bilhões, em 2000. Isso significa que o crescimento populacional mundial entre 1960 e 2000, ou seja, durante 40 anos, foi igual ao ocorrido entre 1800 e 1960, durante 160 anos. Decorridas duas décadas do século XXI, a população mundial aumentou em 1,6 bilhão, somando em 2019 o total de 7,7 bilhões. $^{3}$

Esse expressivo crescimento populacional dos últimos 60 anos foi fruto dos avanços e impactos do desenvolvimento industrial e da tecnociência. Fez-se acompanhado de mudanças nas formas e nos lugares de vida da população, assim como na sua produção e reprodução econômica. Em termos espaciais, inicialmente a industrialização promoveu um processo de esvaziamento do campo e o aumento do tamanho e do número de cidades, embora com expressões e temporalidades diferenciadas, variando de acordo com as realidades de cada país e região. Em um segundo momento, associado à migração para a cidade, foi sendo ampliada a área urbana e seus tentáculos, assim como a urbanização do campo, com a introdução de objetos técnicos - que vão desde a construção de estradas e de ferrovias até maquinários e sementes transgênicas, por exemplo - e de informações e modos de vida diferentes dos que predominavam localmente.

\footnotetext{
${ }^{3}$ The Population Division of the Department of Economic and Social Affairs of the United Nations, ONU (https://www.un.org/development/desa/pd/sites/www.un.org.development.desa.pd/files/files/ documents/2020/Jan/wpp2019_highlights.pdf).
} 
Os centros urbanos também se amplificaram e outros tantos surgiram. Metrópoles, megacidades, macrometrópoles, megalópoles, cidades médias e pequenas emergem em várias partes do planeta. Assim, hoje, $55 \%$ da população mundial é urbana, ou seja, aproximadamente 4 bilhões de pessoas. No futuro, embora a projeção dos dados aponte para a diminuição da taxa de urbanização no mundo, pois o planeta todo será urbano, "urbanização generalizada da sociedade", as megacidades, ou as cidades em geral, principalmente nos países pobres, continuarão a crescer a partir das taxas de natalidade e das migrações de outras cidades. ${ }^{4}$

Figura 1. População urbana e rural no mundo, 1950-2050

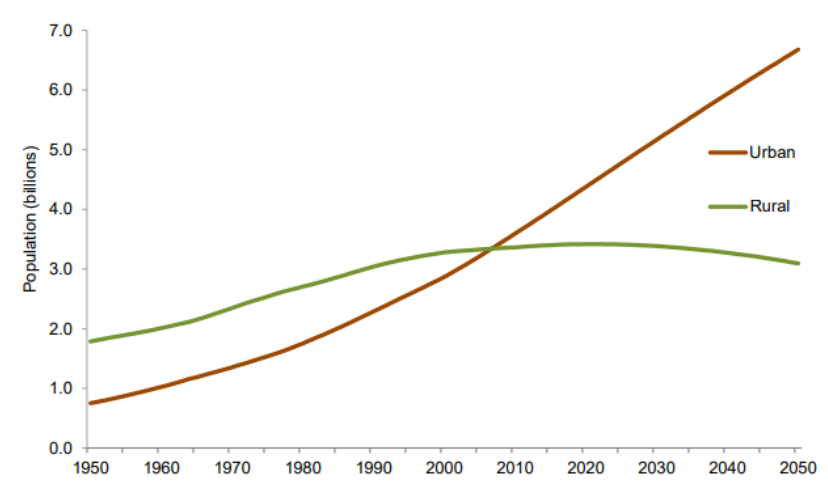

Fonte: United Nations, Department of Economic and Social Affairs, Population Division (2018). World Urbanization Prospects, 2018. https://population.un.org/wup/Publications/Files/WUP2018- Highlights.pdf.

Espacialmente, o crescimento populacional mundial das últimas décadas se concentrou nas regiões mais pobres do planeta; portanto, esteve fortemente associado ao início e espraiamento da urbanização nessas regiões. ${ }^{5}$ Atualmente, as regiões mais pobres são as que possuem a maior população urbana do mundo. Por exemplo, em 1950, cerca de $58 \%$ da população urbana mundial estava nos países ricos, contra $42 \%$ nos pobres, e em 2005 apenas $28,4 \%$ da população urbana mundial encontrava-se nos países ricos, contra $71 \%$ nos pobres. As figuras 2 e 3 , a seguir, ilustram essa inversão. Apresentam, de um lado, o crescimento da população urbana e, de outro, a diminuição da taxa de variação da população rural por regiões geográficas.

\footnotetext{
${ }^{4}$ https://www.un.org/en/events/citiesday/assets/pdf/the_worlds_cities_in_2018_data_booklet.pdf.

${ }^{5}$ Basicamente regiões da África, Ásia (excluindo o Japão), América Latina e Caribe.
} 
Figura 2. Porcentagem da população residente em áreas urbanas por região geográfica, 1950-2050.
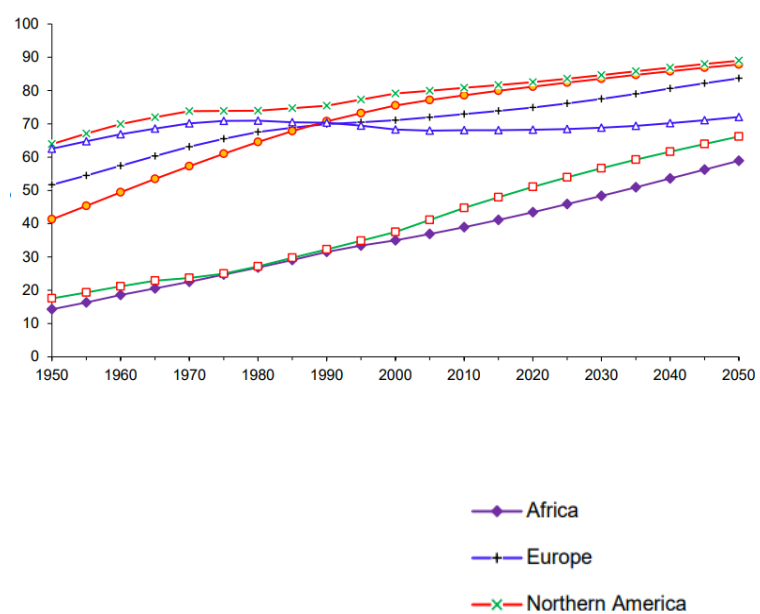

Figura 3. Taxa média anual de variação da população rural por região geográfica, 1950-2050.

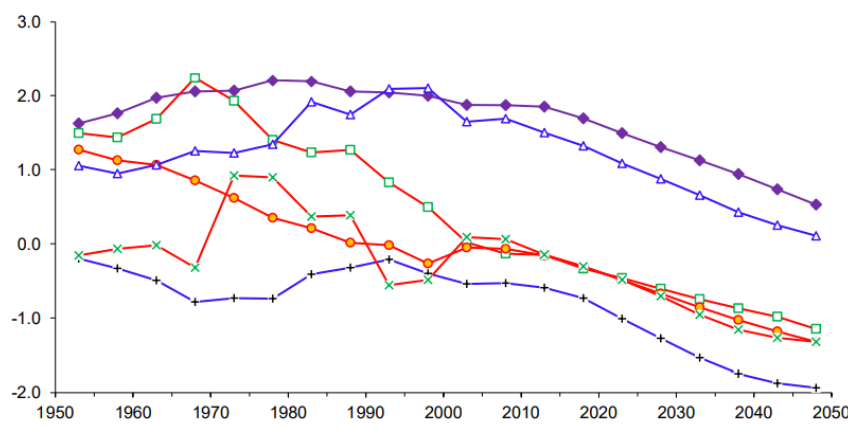

$\longrightarrow-$ Asia

$\multimap-$ Latin America and the Caribbean

$\rightarrow-$ Oceania

Fonte: World Urbanization Prospects: The 2018 Revision, United Nations New York, 2019 (https://population.un.org/wup/Publications/Files/WUP2018-Report.pdf).

A urbanização mundial pode ser mais bem observada na figura 4, que apresenta a porcentagem urbana da população e as aglomerações com 500 mil habitantes ou mais, em 2018. As duas gradações mais fortes de azul indicam os países predominantemente urbanos, com $60 \%$ ou mais de sua população urbana. 0 tom mais escuro apresenta os países com $80 \%$ ou mais. Os círculos representam e localizam as aglomerações com 500 mil habitantes ou mais. Apesar dos diferentes processos de urbanização dos países e continentes, chama a atenção o azul escuro do continente americano de um lado e a concentração de aglomerações urbanas na Índia e leste da China.

Figura 4. População urbana e rural no mundo, 1950-2050

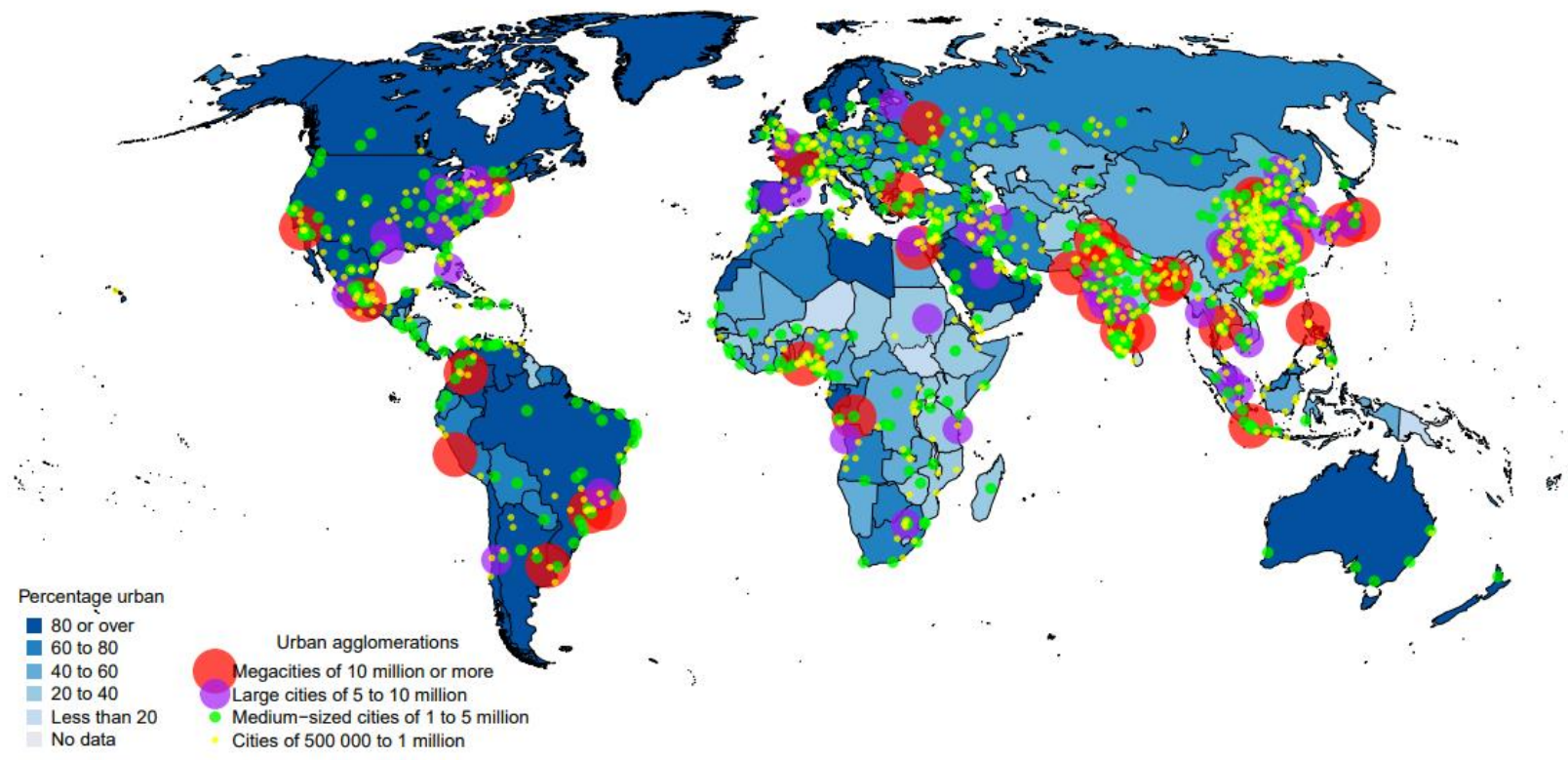

Fonte: World Urbanization Prospects: The 2018 Revision, United Nations New York, 2019.

(https://population.un.org/wup/Publications/Files/WUP2018-Report.pdf). 
No caso americano, é possível identificar grandes regiões urbanizadas, verdadeiros sistemas urbanos policêntricos, de intensa circulação de mercadorias, pessoas, ideias e capital. O espraiamento da técnica no território promoveu, assim, uma transformação estrutural da sociedade, sobretudo pela interação de todos os pontos em um contínuo urbano-rural. O campo se urbanizou cada vez mais, a ponto de a população rural não precisar mais migrar para a cidade; a cidade passou a ir até ela (GULDIN apud DAVIS, 2006, p. 19). ${ }^{6} \mathrm{Na}$ América Latina a população urbana e a urbanização do território se intensificaram muito na década de 1970 , fruto dos investimentos de capitais internacionais das duas décadas anteriores. Não apenas o crescimento de núcleos dentro das regiões metropolitanas foi expressivo, principalmente das áreas periurbanas, como também o aumento do número de cidades de portes pequeno e médio.

No Brasil, a partir da década de 1960, ponto de inflexão da população urbana com relação à população total, quando o crescimento numérico da população urbana brasileira ultrapassou o da população total, as cidades passaram a se espalhar por todos os estados e regiões do país, constituindo uma rede urbana ainda mais ampla e complexa, produto do prolongamento da política desenvolvimentista de Juscelino Kubitschek e do governo militar. As modernizações introduzidas pelo chamado complexo técnico-militar e seus sistemas de planejamento haviam acoplado as políticas urbanas às regionais, promovendo ao mesmo tempo uma desconcentração da urbanização, principalmente do Rio de Janeiro, e a criação de polos de desenvolvimento regionais e políticas de cidades médias pelo país, embora o estado de São Paulo continuasse a ampliar o setor empresariado privado e sua população urbana, numa proporção bem superior à do Rio de Janeiro. Assim, durante a década de 1980, o modo de vida urbano foi estendido para além do Sudeste e das grandes cidades e regiões metropolitanas. Ampliaram-se não apenas a extensão e o número das cidades grandes, mas também das médias e pequenas, a partir do desenvolvimento dos sistemas tradicionais e modernos de transporte, telecomunicação e informação.

Figura 5. População urbana e rural no Brasil, 1970-2010.

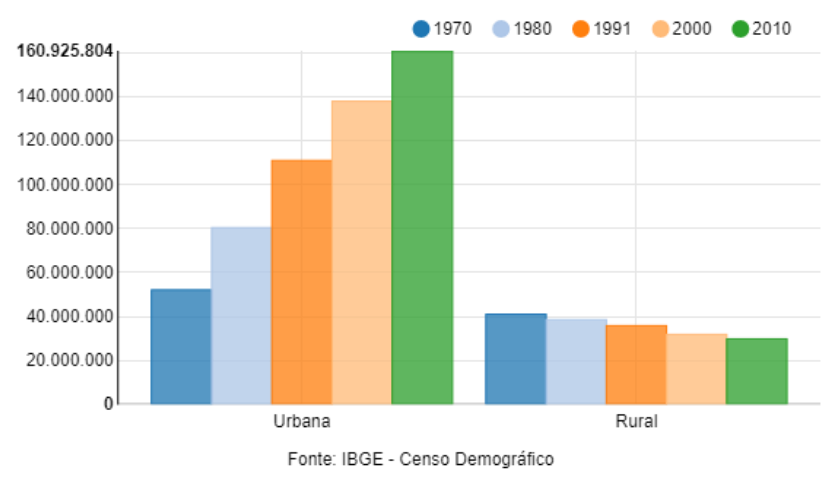

Figura 6. Número de cidades no Brasil e por regiões, 1950-2010.

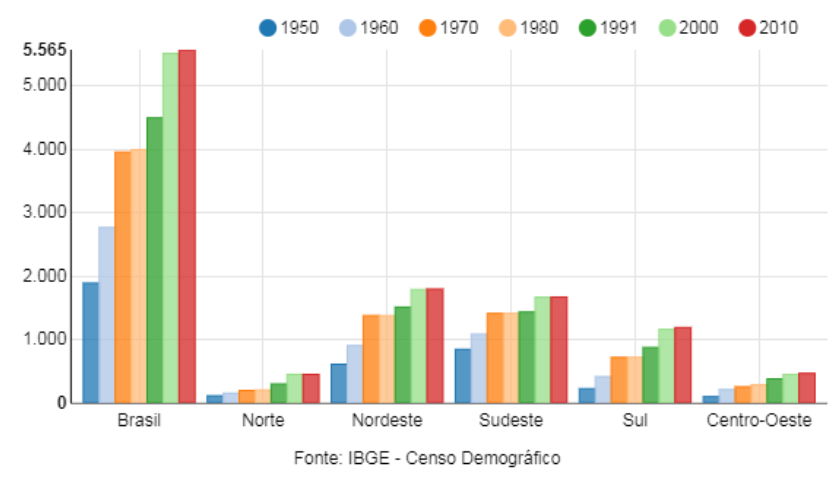

\footnotetext{
${ }^{6}$ Embora Gregory Guldin tenha como base de observação a dinâmica da urbanização chinesa, a ideia de a cidade ir até a população rural parece bem interessante para pensar o caso latino-americano, principalmente o brasileiro, mantendo, é claro, as devidas singularidades do processo histórico de ambos os lugares.
} 
A sociedade brasileira se alterou muito qualitativa e quantitativamente a partir de 1960, na realidade durante os vinte anos da política militar. A desconcentração da urbanização no Sudeste pode ser sentida a partir da ampliação do número de cidades no Nordeste, principalmente, mas também na região Sul, no período mencionado. Aumento que se mantém nas mesmas proporções até 2010, com a ampliação do país no mundo da globalização, a qual, ao abrir o mercado nacional ao comércio internacional, dinamizou sua tecnociência e estendeu o meio técnico-científico para além do eixo tradicional de desenvolvimento econômico industrial brasileiro, Rio-São Paulo.

Figuras 7 e 8 - População nas cidades, 1950 e 2010.
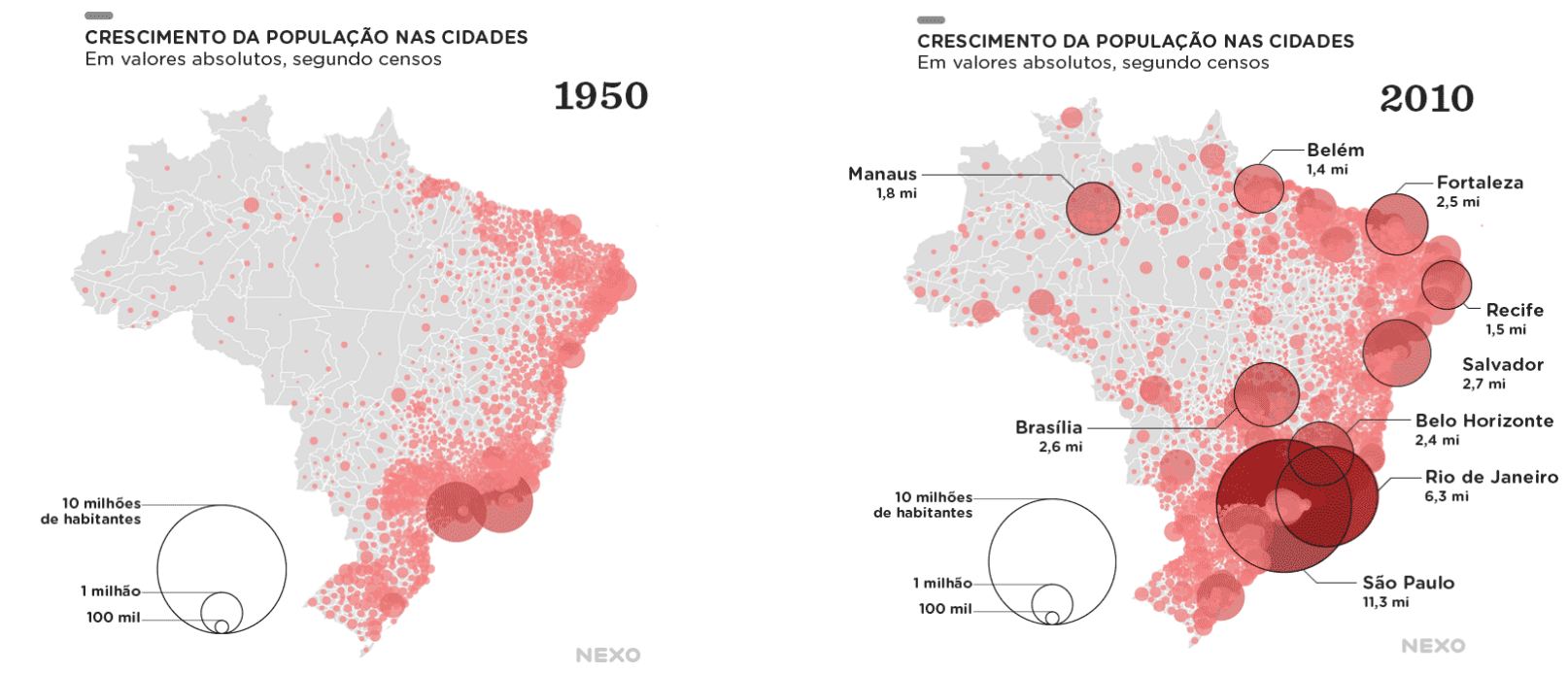

Fonte: Nexo Jornal (https://www.nexojornal.com.br/interativo/2017/09/25/Compare-a-densidade-populacional-das-cidades-nestemapa-interativo).

Dados atuais levantados pelo Instituto Brasileiro de Geografia e Estatística (IBGE), em 2020, confirmam essa tendência. Com uma população brasileira estimada em cerca de 212 milhões de habitantes, 24\%, ou seja, mais de 50 milhões, estão nas 27 capitais. A região metropolitana de São Paulo continuou sendo a mais populosa (22 milhões de habitantes), seguida pelas regiões metropolitanas do Rio de Janeiro (13 milhões), Belo Horizonte (6 milhões) e Brasília (5 milhões). As taxas de crescimento das maiores regiões metropolitanas do país (São Paulo, Rio de Janeiro, Belo Horizonte, Porto Alegre, Fortaleza, Recife e Salvador) continuam aumentando, embora sejam ligeiramente inferiores à média do país. O mesmo se verifica nos municípios que têm entre 100 e 1 milhão de habitantes, que apresentaram as maiores taxas de crescimento, com destaque para as regiões Norte e CentroOeste. ${ }^{7}$ Assim, o processo de urbanização no Brasil tem prosseguido em ritmo de crescimento, ampliando-se não

\footnotetext{
${ }^{7}$ IBGE (https://agenciadenoticias.ibge.gov.br/agencia-sala-de-imprensa/2013-agencia-de-noticias/releases/28668-ibge-divulgaestimativa-da-populacao-dos-municipios-para-2020).
} 
apenas nas grandes metrópoles, embora em taxas menores, como também nas cidades médias e em todo o território brasileiro, através da expansão dos transportes, das comunicações e das redes técnicas para além dos limites da cidade.

\section{O crescimento protestante pentecostal no Brasil}

Apesar de o Brasil ainda seguir como o maior país católico do mundo, o aumento da população protestante tem sido uma tendência desde meados do século XX. O percentual de católicos vem diminuindo e o de protestantes ou evangélicos ampliando-se gradativamente: em 1890, os evangélicos representavam 1\% da população total brasileira; em 1900, 1,1\%; em 1940, 2,6\%; em 1950, 3,4\%; em 1960, 4\%; em 1970, 5,2\%; em 1980, 6,6\%; em 1991, 12,25\%; em 2000, 15,4\%; e em 2010, $22 \% .{ }^{9}$ No último censo demográfico realizado no país, em 2010 , do total da população, os católicos já representavam $65 \%$ e os evangélicos $22 \%$. É interessante observar que entre as décadas de 1980 e 1990 o crescimento dos protestantes quase dobrou. ${ }^{10}$ Destes, foram os pentecostais que se tornaram mais numerosos, chegando a representar 60\% do total dos protestantes no Brasil em 2010.

Figura 9. Histórico das religiões no Brasil

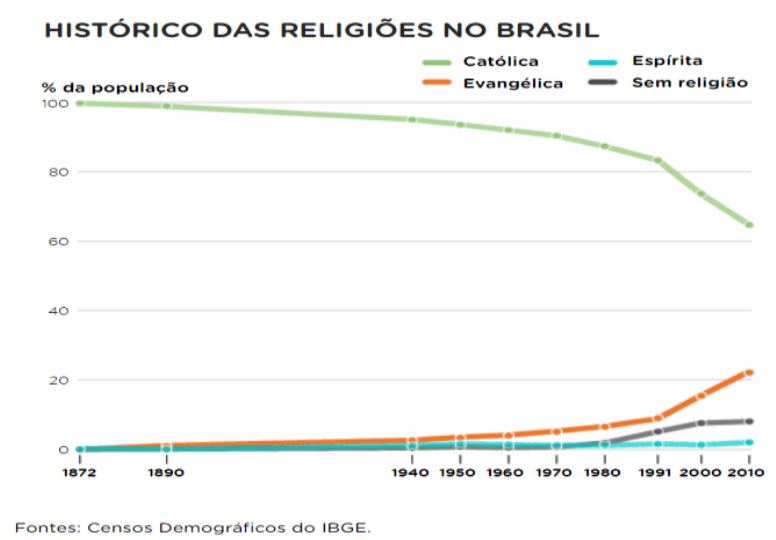

Como religiosidade popular e essencialmente urbana, o pentecostalismo surgiu no Brasil no início do século XX, trazido por missionários estrangeiros, em 1910, na capital paulista, com a Congregação Cristã do Brasil (cisão dos protestantes presbiterianos), e em Belém do Pará, em 1911, com a Assembleia de Deus (cisão dos protestantes batistas). Na década de 1930, com o aumento do fluxo migratório houve um aquecimento de sua difusão, e, na década de 1950, o pentecostalismo passou a estar presente em todo o território nacional, com mais duas grandes

\footnotetext{
8 Dados recolhidos e tabulados em ROLIM, 1985 e no Censo Demográfico IBGE, 1980, 1991, 2000.

${ }^{9}$ Censo Demográfico IBGE, 2010 (http://www.sidra.ibge.gov.br/cd/cd2010CGP.asp?o=13\&i=P).

10 “Esse processo de transição religiosa não é exclusivo do Brasil, mas ocorre em outros países da América Latina. O estudo 'Religião na América Latina, do Instituto de Pesquisas pew (2014), mostrou que o número de pessoas que se declaram protestantes continua crescendo em todo o continente, enquanto aquelas criadas no catolicismo vêm deixando a religião". (ALVES, et al. 2017, p. 216-217).
} 
denominações, o Evangelho Quadrangular (SP) e o Brasil para Cristo (SP), e uma série de outras igrejas menores. No final dos anos de 1960 e durante a década de 1970, associada ao crescimento da urbanização, a expansão pentecostal continuou por todo o país, chegando a mais de 70 denominações, com destaque para as igrejas Assembleia de Deus (criada em Belém, atualmente a mais numerosa em igrejas e fiéis), Congregação Cristã do Brasil (criada em São Paulo), Universal do Reino de Deus (criada no Rio de Janeiro), Evangelho Quadrangular (criada em São Paulo), Deus é amor (criada em São Paulo), Maranata (criada no Espírito Santo), Brasil para Cristo (criada em São Paulo), Casa da Bênção (criada em Belo Horizonte) e Nova Vida (criada no Rio de Janeiro). De lá para cá, não apenas o número dessas igrejas e de seus membros continuou se ampliando como surgiu uma série de novas igrejas, novas denominações, muitas criadas por antigos membros das denominações existentes. ${ }^{11}$

O crescimento pentecostal, que se registrou sobretudo a partir de meados da década de 1970, foi impulsionado pelas igrejas que passaram a ser denominadas neopentecostais, como a Universal do Reino de Deus, a Internacional da Graça de Deus, a Comunidade Evangélica Sara Nossa Terra, a Renascer em Cristo, a Igreja Mundial do Poder de Deus, a Internacional da Graça de Deus e tantas outras. Segundo Ricardo Mariano (2004), no plano teológico, essas igrejas se caracterizam e se diferenciam das pentecostais anteriores, sobretudo por enfatizar a guerra espiritual contra o Diabo e seus representantes na Terra e pela Teologia da Prosperidade. Completamente adaptada aos valores e ao pragmatismo do capitalismo atual, a Teologia da Prosperidade difunde a crença de que o cristão deve ser próspero, saudável, feliz e vitorioso em seus empreendimentos terrenos.

\begin{abstract}
Daí seus cultos basearem-se na oferta especializada de serviços mágico-religiosos, de cunho terapêutico e taumatúrgico, centrados em promessas de concessão divina de prosperidade material, cura física e emocional e de resolução de problemas familiares, afetivos, amorosos e de sociabilidade. Oferta sob medida para atender a demandas de quem crê que pode se dar bem nesta vida e neste mundo recorrendo a instituições intermediárias de forças sobrenaturais. (MARIANO, 2004, p. 124).
\end{abstract}

Assim, sem romper com valores religiosos e costumes conservadores, a Teologia da Prosperidade foi fundamental para que igrejas neopentecostais rompessem com a rigidez das tradicionais pentecostais, que era facilmente identificada nas vestimentas e no estilo de vida dos seus membros. As neopentecostais passaram a ser mais liberais nos comportamentos e no consumo, permitindo e incentivando, pela ideologia do empreendedorismo, o uso de roupas da moda, cosméticos e diversificados produtos estéticos, liberando, ainda, a frequência a praias, piscinas, cinemas, teatros, shows, etc. Com o passar do tempo foram surgindo grupos e produtos variados, direcionados ao crescente mercado evangélico, cada vez mais ampliado pela internet e pelas redes sociais. Essas mudanças comportamentais também passaram a ser verificadas nas antigas denominações pentecostais, que começaram a se difundir espacialmente a partir de igrejas renovadas. Portanto, sem perder a distintividade religiosa, as igrejas neopentecostais não só se acomodaram mais

\footnotetext{
11 No Censo 2010, a Igreja Assembleia de Deus, a maior denominação evangélica pentecostal do país, tinha 12.314 .410 adeptos; a Congregação Cristã do Brasil, a segunda maior, 2.289.634; a terceira, a Universal do Reino de Deus, 1.873.243; a quarta, a Evangelho Quadrangular, 1.808.389; a quinta, a Deus é Amor, 845.383; a sexta, a Maranata, 356.021; a sétima, Brasil Para Cristo, 196.665; a oitava, a Casa da Bênção, 125.550. Outras denominações evangélicas somavam, ao todo, 5.267.029 de adeptos.
} 
rapidamente à sociedade, seus valores, interesses e práticas, como também passaram a ser seguidas em suas dinâmicas e estratégias de difusão.

Como uma religiosidade essencialmente urbana, é interessante observar a associação da difusão do pentecostalismo no Brasil à expansão da urbanização do território, no sentido do espraiamento das redes técnicas no espaço brasileiro. Os números absoluto e relativo de pentecostais são maiores não apenas nos espaços mais urbanizados, incluindo as metrópoles e cidades médias e pequenas, como também nas áreas rurais menos urbanizadas. Assim, embora se possa reconhecer que as condições urbanas foram e ainda são favoráveis à difusão do protestantismo pentecostal - por estabelecerem novas condições materiais advindas da industrialização e migração do campo -, atualmente o seu crescimento parece estar mais diretamente associado às mudanças comportamentais decorrentes desses processos, como as alterações dos sistemas de valores e da tradicional estrutura social impulsionada pela dinâmica capitalista atual, que atinge não só as cidades, mas os antigos espaços rurais.

Nesse sentido, o estudo realizado por Alves et al. (2017) apresenta dados e considerações interessantes que ilustram tanto a alteração da composição religiosa brasileira, pela perda da hegemonia católica e o aumento da pluralidade religiosa, principalmente dos protestantes, como o padrão espacial dessa transição. Segundo os autores, pela primeira vez na história o número absoluto de católicos caiu entre os anos de 2000 e 2010. Enquanto os católicos encolheram, os evangélicos cresceram, sobretudo os pentecostais. O número de católicos cresceu em termos absolutos, mas apresentou redução relativa no meio urbano, enquanto no meio rural o declínio ocorreu em termos absoluto e relativo. Já os evangélicos apresentaram crescimento absoluto e relativo tanto nas áreas urbanas como rurais, aumentando sua participação em $98 \%$ das cidades. Conforme Alves et al. (2017) destacam, o padrão espacial da expansão evangélica na sua parte mais avançada está no arco periférico das maiores regiões metropolitanas, seguindo para os núcleos dessas mesmas regiões, avançando para as cidades de maior porte populacional, seguindo para as cidades menores e áreas rurais. Embora, em termos de volume, a região Sudeste tenha quase a metade de todos os evangélicos brasileiros, a região Norte apresentou maior crescimento relativo do grupo de evangélicos. Em seguida está a região CentroOeste e a região Sudeste. As áreas de fronteira agrícola e colonização recente na região Norte também se destacam.

As três figuras, a seguir, buscam ilustrar esse processo de transição religiosa, demonstrando o crescimento evangélico entre os anos de 1991 e 2010. 
Figuras 10, 11 e 12. A expansão protestante no Brasil, 1991-2010.
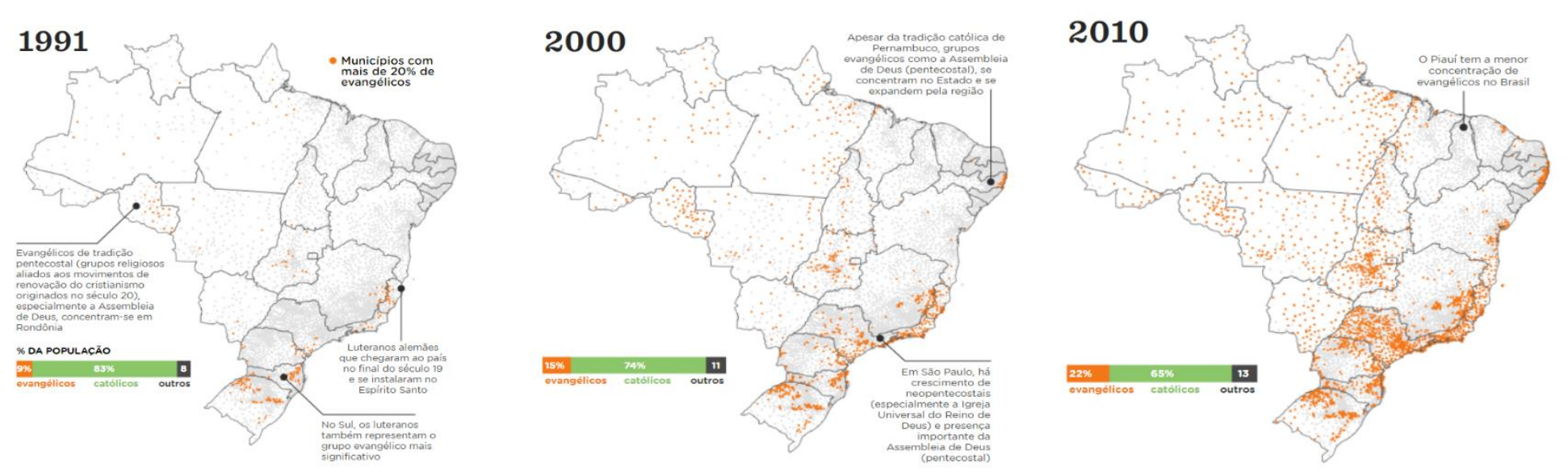

Fonte: Nexo Jornal. (https://www.nexojornal.com.br/grafico/2017/11/06/A-expans\%C3\%A3o-evang\%C3\%A9lica-no-Brasilem-26-anos).

\section{A Igreja Universal do Reino de Deus, do Méier para o mundo}

A revitalização religiosa, em suas variadas formas, é uma das mais visíveis transformações culturais da urbanização. O aumento da diversidade religiosa e a perda da hegemonia católica no mundo sul-americano são, sobretudo, fenômenos urbanos, o que não poderia ser diferente, em função da amplitude do urbano na América e no mundo desde as últimas décadas do século XX, ou seja, a urbanização generalizada, teórica e empiricamente explorada anteriormente. Ao invés do retorno à tradição, os novos grupos e expressões religiosas que surgem podem ser vistos como formas de adaptação e sobrevivência às circunstâncias e aos desafios do mundo urbano-metropolitano. É o caso da Igreja Universal do Reino de Deus, uma ramificação do protestantismo pentecostal, o neopentecostalismo. ${ }^{12}$ Assim como outras igrejas neopentecostais, mas com maior ênfase, a Universal associou seu discurso religioso à Teologia da Prosperidade, que se sustenta na ideologia da busca pela felicidade integral ainda durante a vida sobre a Terra, apoiada incondicionalmente em Jesus, estimulando o consumo, a organização empresarial e a atitude empreendedora. A ideia de prosperidade vai se refletir também nos seus investimentos econômicos, políticos e estéticos, principalmente arquitetônicos. $^{13}$

\footnotetext{
${ }^{12}$ As igrejas protestantes são de origem cristã e, no Brasil, se constituem, basicamente, por duas grandes ramificações: as históricas (são as tradicionais, as quais no último Censo do IBGE foram denominadas de igrejas de missão) e as pentecostais. Nestas últimas estão inseridas as igrejas pentecostais renovadas, que emergiram das igrejas tradicionais, e as igrejas pentecostais que já surgiram como tais, tanto antigas denominações quanto novas, estas reconhecidas como neopentecostais, criadas em finais da década de 1970 (para um panorama e discussão sobre os evangélicos no Brasil, ver Rolim, 1985; Machado, 1993; Mafra, 2001; Mariano, 2004; Machado e Nacif, 2004).

${ }^{13} \mathrm{~A}$ arquitetura e a estética das igrejas sedes, catedrais e dos novos megatemplos da Universal refletem e materializam claramente a ideologia da prosperidade. A Catedral Mundial da Fé, no Rio, e sobretudo o Templo de Salomão, em São Paulo, são exemplos de sua arquitetura religiosa da prosperidade. "O objetivo é abrir a cabeça do pobre que dá oferta. Na sua casa, ele senta no sofá rasgado ou até no chão. Na igreja, ele é honrado. Tem o direito de sentar em uma cadeira estofada, com ar condicionado, usar um banheiro limpo. Recebe um atendimento exemplar. Eu quero mostrar que ele é capaz de conquistar coisas grandes, uma vida melhor. Algo como dizer:
} 
A Igreja Universal do Reino de Deus foi uma criação eminentemente brasileira, de iniciativa do então pastor Edir Macedo, hoje bispo e grande empresário do mercado religioso, com forte influência na política nacional. Na realidade, a Universal foi criada por Edir Macedo, Romildo Soares e Roberto Augusto, em 1977, como um ponto de pregação, reunindo crentes no subúrbio carioca em torno de um pequeno coreto, em uma praça pública, no bairro do Méier. No mesmo ano, instalaram a primeira igreja em uma antiga funerária, em um bairro vizinho, na Abolição. ${ }^{14}$ Assim, do subúrbio carioca a Universal passou a se difundir pelo país, e já na década de 1980 estava presente em todas as regiões brasileiras. A partir de 1985 se expandiu para o continente americano e, posteriormente, para o europeu, africano e asiático. ${ }^{15}$

Conforme indicam os dados do site e do blog da Universal aqui tabulados, atualmente a igreja possui aproximadamente 10.400 templos (aqui estão incluídos tanto pontos de pregação quanto serviços de evangelização) em 146 países, e está presente em todos os continentes, especialmente no sul-americano, que concentra 77\% desse total, ou seja, cerca de 8.000 templos, dos quais 7.050 estão no Brasil. Os dados chamam a atenção para o aumento da atuação da Universal na África. Nos últimos 10 anos, o número de templos no continente africano quadruplicou, passando de 247, em 2010, para 1.049, em 2020, com destaque para a África do Sul, Angola e Moçambique. ${ }^{16}$

No território brasileiro, a região Sudeste concentra $40 \%$ das igrejas, seguida pelas regiões Nordeste, com $29 \%$, Sul, com $12 \%$, e Norte e Centro-Oeste, com $10 \%$ cada uma. São Paulo é o estado com maior número de igrejas, seguido pelo Rio de Janeiro, Minas Gerais e Bahia. ${ }^{17}$

\footnotetext{
veja a grandeza de Deus. Sua casa é um barraco? Olha o que Deus pode fazer. A Igreja Universal também começou em um barraco, mas olha como está hoje. Você precisa investir nesse Deus". (Edir Macedo apud LEMOS; TAVOLARO, 2007. p. 208).

${ }^{14} \mathrm{Em}$ finais da década de 1980, Roberto Augusto saiu da Universal e retornou à sua igreja de origem, a Igreja Nova Vida, e ingressou na política do Rio de Janeiro, inicialmente pelo DEM e, posteriormente, pelo PTB. Entretanto, não deu continuidade à vida política. Romildo Ribeiro Soares, o Missionário R.R. Soares, cunhado de Edir Macedo, deixou a Universal em 1980 e fundou a Igreja Internacional da Graça de Deus, no Rio de Janeiro. Tornou-se empresário, advogado, escritor, cantor e compositor evangélico, e ainda um importante apresentador de programas evangélicos, veiculados tanto em rede de televisão aberta (Rede Bandeirantes, Rede TV! e Rede Internacional de Televisão, fundada pela sua igreja) quanto em TVs por assinatura, assim como pelo Youtube e outras mídias, obtendo alcance internacional.

${ }^{15}$ A expansão internacional da Universal data de 1985, quando ela abriu uma igreja no Paraguai. Em 1986, instalou-se nos Estados Unidos, e em 1989, na Argentina, no Uruguai e em Portugal. Inicialmente sua expansão internacional foi lenta, passando a se acelerar a partir de 1990. Em 1995, o número de templos no exterior era estimado em 221; em 1998, em 500; e em 2001, em 1000. (ORO, 2004). A partir de 2000, a Universal alcançou todos os países da América Latina e se expandiu com força para a África (principalmente África do Sul, Angola e Moçambique). Seu crescimento continuou na América do Norte, sobretudo nos EUA, na Europa, com destaque para Portugal e Inglaterra, no Leste Europeu e na Ásia, principalmente no Japão.

${ }^{16}$ Os dados da Universal na África foram levantados 10 anos atrás no site da Universal (http://www.igrejauniversal.org.br), e os dados atuais, de 2020, no blog da Universal (https://universalenderecos.wordpress.com). Contudo, cabe uma observação sobre essas fontes de informações. O site e o blog da Universal não são de fácil consulta e não fornecem o total de templos nos continentes e países. Para este levantamento foi necessário acessar país por país e sistematizar tabelas para análise, que serviram de fonte para este trabalho. Contudo, cabe mencionar que os censos demográficos do IBGE realizados em 2000 e 2010 apontam diminuição do número de crentes da Universal, que passaram de 1,24\% da população brasileira, em 2000, para 1\% em 2010. Já na Assembleia de Deus, no mesmo período, houve um aumento de 1,5\% em 2000. Apesar da diminuição do número de evangélicos da Universal, apontada no Censo, sua expressão política se ampliou.

17 https://universalenderecos.wordpress.com.
} 
Figura 13. Distribuição dos templos da Universal no Brasil, por regiões, 2020.

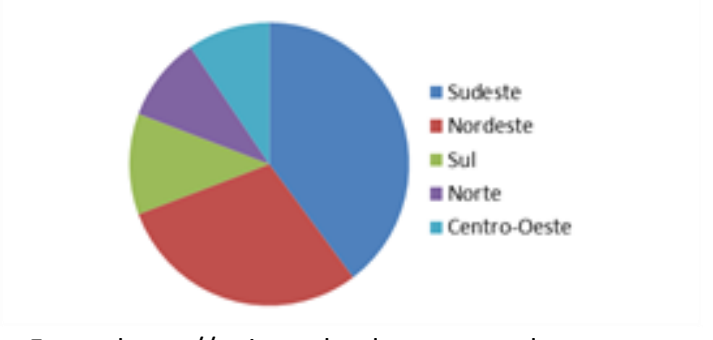

Fonte: https://universalenderecos.wordpress.com.

A principal igreja da Universal no Brasil está localizada, hoje, na cidade de São Paulo, no bairro do Brás, o Templo de Salomão. Inaugurado em 2014, o Templo foi construído para se tornar sua nova sede mundial em substituição à antiga, no Rio de Janeiro, no bairro de Del Castilho, a Catedral Mundial da Fé, que passou à categoria de sede estadual. São Paulo, portanto, tornou-se a nova centralidade da Universal no Brasil e no mundo, e o Templo de Salomão foi erguido para ser o seu símbolo. Um megaempreendimento religioso, com uma arquitetura grandiosa e uma estética judaica impactante, o Templo foi construído à imagem do Templo de Salomão descrito na Bíblia Hebraica, ou seja, no Antigo Testamento. Com capacidade para 10 mil pessoas e com uma área construída quatro vezes maior do que a maior catedral católica brasileira no interior paulista, o Santuário Nacional de Nossa Senhora Aparecida, esse megatemplo acabou se tornando também um centro de extraordinária atração turística, impactando os preços dos imóveis e os usos da terra em seu entorno. A importância e a imponência do Templo de Salomão são também reverberadas diretamente na esfera da política nacional. Na sua inauguração, em 2014, ano de eleição presidencial, no qual Dilma Rousseff concorria à reeleição, estiveram presentes nada menos do que a então presidente da República, Dilma Rousseff (PT), o vice-presidente, Michel Temer (PMDB), o governador do estado, Geraldo Alckmin (PSDB), e o prefeito de São Paulo, Fernando Haddad (PT). Em setembro de 2019, o atual presidente da República, Jair Bolsonaro (então no PSL), foi batizado no Templo, pelo bispo Edir Macedo. ${ }^{18}$

Tanto em território brasileiro quanto internacionalmente, a expansão da Universal se tornou mais expressiva no início dos anos 1990, quando realizou a compra da Rede Record de Televisão. ${ }^{19}$ Hoje a TV Record está presente também nos EUA, Europa e África, transmitindo para 160 países programas e produtos elaborados aqui, além dos que são especificamente direcionados para a comunidade brasileira fora do país. É interessante observar que, justamente nos últimos 10 anos, quando a Record entrou de forma efetiva no continente africano, entre 2010 e 2020, a Universal registrou um significativo crescimento do número de

\footnotetext{
${ }^{18}$ Embora católico, Jair Bolsonaro já havia sido batizado anteriormente pelo pastor evangélico Everaldo Dias Pereira, da Assembleia de Deus. Postado em vídeo nas redes sociais, esse batismo ocorreu em 2016, no rio Jordão, em Israel, no mesmo dia em que o Senado brasileiro votava a admissibilidade do impeachment da então presidente Dilma Rousseff.

${ }^{19}$ A expansão da Universal foi acelerada na década de 1990, quando a Igreja passou a ter controle acionário da Rádio e da TV Record. Desde então, a implantação de templos da Universal no Brasil e no mundo passou a ser impulsionada pela extensa e forte programação religiosa desses veículos de comunicação.
} 
templos e de fiéis na África, conforme indicado anteriormente. Se na década de 1980 a difusão e a reprodução da Universal se realizavam no plano do cotidiano, sobretudo da população mais pobre, nas décadas posteriores ela ampliou seu alcance apoiada no uso intensivo dos meios de comunicação e passou a conquistar não apenas a simpatia e o apoio da classe média, mas também de setores empresariais e de políticos, que rapidamente compreenderam a importância do apoio evangélico no pleito eleitoral. ${ }^{20}$ Não demorou muito e pastores e fiéis da Universal passaram a se candidatar e entrar igualmente para a vida política, tornando-se vereadores, prefeitos, deputados estaduais, deputados federais e senadores. E com o passar do tempo a Universal conseguiu articular ao redor do seu eixo uma grande frente política de força nacional, a frente evangélica. ${ }^{21}$

Assim, a Universal acabou se tornando uma das maiores representações religiosas e políticas do neopentecostalismo brasileiro, com grande e diversificada capacidade de difusão, apoiada tanto pelas suas estratégias territoriais originárias quanto pelo uso dos meios de comunicação tradicionais e modernos, como rádio, televisão, jornais, revistas e livros impressos, internet, com sites, blogs e redes sociais. Suas ações no

\footnotetext{
${ }^{20}$ Embora cada vez mais acentuada e frequente, em função do aumento do número de brasileiros evangélicos, a aproximação de políticos com as igrejas pentecostais não é nova e tem sido realizada por diversos partidos, com bases ideológicas distintas, seja de esquerda, de centro ou de direita. Nas eleições presidenciais de 2002, por exemplo, Luiz Inácio Lula da Silva (PT) se aproximou dos evangélicos, de quem recebeu apoio no primeiro e segundo turnos. No primeiro foi apoiado pelas igrejas Metodista, Batista, Sara Nossa Terra, Universal do Reino de Deus e Assembleia de Deus. No segundo turno os evangélicos ficaram divididos entre Lula (PT) e Serra (PSDB), mas a Universal do Reino de Deus manteve seu apoio a Lula, que tinha como vice o empresário e político paulista José Alencar. Em 2003, no primeiro ano do mandato do PT na presidência da República, José Alencar, Edir Macedo e seu sobrinho Marcelo Crivella, este também da Universal, criaram o Partido Municipalista Renovador, que obteve registro em 2005, mudando sua sigla para Partido Republicano Brasileiro. Em 2019, a sigla foi alterada novamente, agora para Republicanos, onde hoje estão filiados dois filhos do atual presidente da República, Flávio e Carlos Bolsonaro. Na segunda disputa para a presidência da República, em 2006, Lula e José Alencar mantiveram a base evangélica, sobretudo da Assembleia de Deus e da Universal do Reino de Deus. Na primeira eleição de Dilma Rousseff à presidência da Republica, em 2010, o PT ainda contava com os evangélicos, e a continuidade do apoio da Universal foi fundamental. Contudo, na segunda metade da década de 2010, o cenário se alterou, e os evangélicos seguiram na direção dos partidos conservadores. É interessante observar, nesse sentido, a movimentação do então deputado federal Jair Bolsonaro na direção dos evangélicos. Em 2013, o pastor Silas Malafaia, da igreja pentecostal Assembleia de Deus Vitória em Cristo, celebrou o casamento de Jair Bolsonaro com Michele Bolsonaro. Evangélica pentecostal, da Igreja Batista da Atitude, filiada à Convenção Batista Carioca, Michele Bolsonaro é amiga de Damares Alves, atual ministra da Mulher, da Família e dos Direitos Humanos e pastora das igrejas Evangelho Quadrangular e Batista da Lagoinha. A indicação de Damares ao ministério, em 2018, em lugar do então senador Magno Malta, de quem era assessora, parece ter sido fortemente influenciada por Michele. Em 2018, Jair Bolsonaro passou a participar do Congresso Internacional de Missões dos Gideões Missionários da Última Hora, um dos maiores encontros das igrejas pentecostais do mundo, que acontece anualmente em Camboriú, Santa Catarina. Também em 2018, na última eleição presidencial disputada entre Jair Bolsonaro (então no PSL) e Fernando Haddad (PT), o importante e influente bispo da Assembleia de Deus, Manoel Ferreira, que esteve ao lado da então candidata Dilma Rousseff em 2014, afirmou seu apoio a Jair Bolsonaro: "Este é o meu candidato a presidente da República, Bolsonaro, 17. Deus acima de tudo". Apoio que Bolsonaro continua mantendo e ampliando entre as maiores denominações pentecostais. Nem o recente episódio do seu veto ao perdão das dívidas das associações e igrejas evangélicas à União, tributos não pagos à Previdência e ao FGTS, parece modificar esse apoio. Logo após o veto, o presidente Bolsonaro postou nas redes sociais a sugestão aos parlamentares de derrubada do seu próprio veto. Conforme matéria publicada na Revista Piauí, em 21 de setembro de 2020 (https://piaui.folha.uol.com.br/dizimos-e-dividas), a dívida de 1,3 bilhão é majoritariamente previdenciária: 60\% desse total são da entidade filantrópica IGASE, Instituto Geral de Assistência Social Evangélica, que tem foco no segmento de hospitais; $20 \%$ referem-se às dívidas de quatro igrejas pentecostais, a Internacional da Graça de Deus, do missionário R.R. Soares (é de autoria de seu filho, o deputado federal David Soares, a emenda que perdoa a dívida das igrejas com a previdência e outros tributos), a Mundial do Poder de Deus (do pastor Valdemiro Santiago), a Renascer em Cristo e a Associação Vitória em Cristo (de Silas Malafaia). O católico Ronaldo Caiado (DEM), atualmente governador do estado de Goiás, um dos membros mais ativos da bancada ruralista no Congresso Nacional, passou também a ampliar sua aproximação com os evangélicos, sobretudo com o influente bispo Manuel Ferreira, da Assembleia de Deus.

${ }^{21}$ Sobre a expressão política do pentecostalismo protestante no Brasil, ver MACHADO e NACIF, 2016.
} 
campo cultural e do entretenimento foram igualmente fundamentais, principalmente frente a um mercado cada vez mais amplo de eventos, shows e espetáculos. Embora essas ações não sejam exclusivas da Universal, nenhuma outra igreja conseguiu ocupar tantos espaços e horários nos meios de comunicação, sobretudo pelo alcance e programação da TV Record, e associou de forma tão evidente fé e política.

Do ponto de vista da estratégia de difusão espacial, a Universal conjugou muito bem uma dinâmica espontânea, a mesma que a originou no Méier, com uma dinâmica moderna, calculada e planejada em rede, possibilitada pelo desenvolvimento dos modernos sistemas e redes técnicas, sobretudo de comunicação. 0 que só foi possível pelas características da estrutura organizacional pentecostal, que é hierarquicamente rígida, mas descentralizada e flexível, muito diferente da estrutura das igrejas protestantes históricas e da igreja católica.

A rigidez pentecostal refere-se à hierarquia de suas instâncias de poder, com um governo legal que organiza e impõe uma linha vertical de diretrizes e ações aos pontos intermediários e mais baixos. A descentralização e a flexibilidade estão na forma "espontânea" de crescimento e difusão, proveniente de evangelizações em pontos de pregação (também denominados de células ou nucleação) realizadas espontaneamente por pessoas das próprias localidades ou por missionários enviados pelas instâncias superiores. Os pontos de pregação ou nucleação constituem, assim, a base de sua hierarquia e podem surgir tanto pelo comando das instâncias de maior poder quanto localmente, por crentes pentecostais simpatizantes da Universal, e, posteriormente, serem incorporados à denominação. ${ }^{22}$ No topo estão os organismos supralocais nas igrejas já consolidadas e na base, os pontos de pregação. Os templos surgem, assim, por uma ação tanto de cima para baixo quanto de baixo para cima. A imagem a seguir ilustra de forma clara esta hierarquia.

\footnotetext{
${ }^{22}$ A evangelização em pontos de pregação, conhecida como prática da nucleação, não é nova e foi implantada pela Assembleia de Deus, uma das primeiras igrejas pentecostais que surgiram no Brasil. É uma prática informal de realização de cultos, através da qual um crente ou um pastor reúne em sua própria casa, ou em qualquer outro lugar, um pequeno grupo de crentes e não crentes. Conforme aumenta a frequência e o número de pessoas nesses cultos, outra estrutura e organização vão se tornando necessárias, um espaço maior e com endereço fixo. Assim, com base em recolhimento de dízimos e/ou com apoio dos templos hierarquicamente superiores, surgem as salas alugadas, destinadas apenas à realização das atividades religiosas e de cultos, os salões. (MACHADO, 1992).
} 
Figura 14. Modelo da estrutura organizacional pentecostal

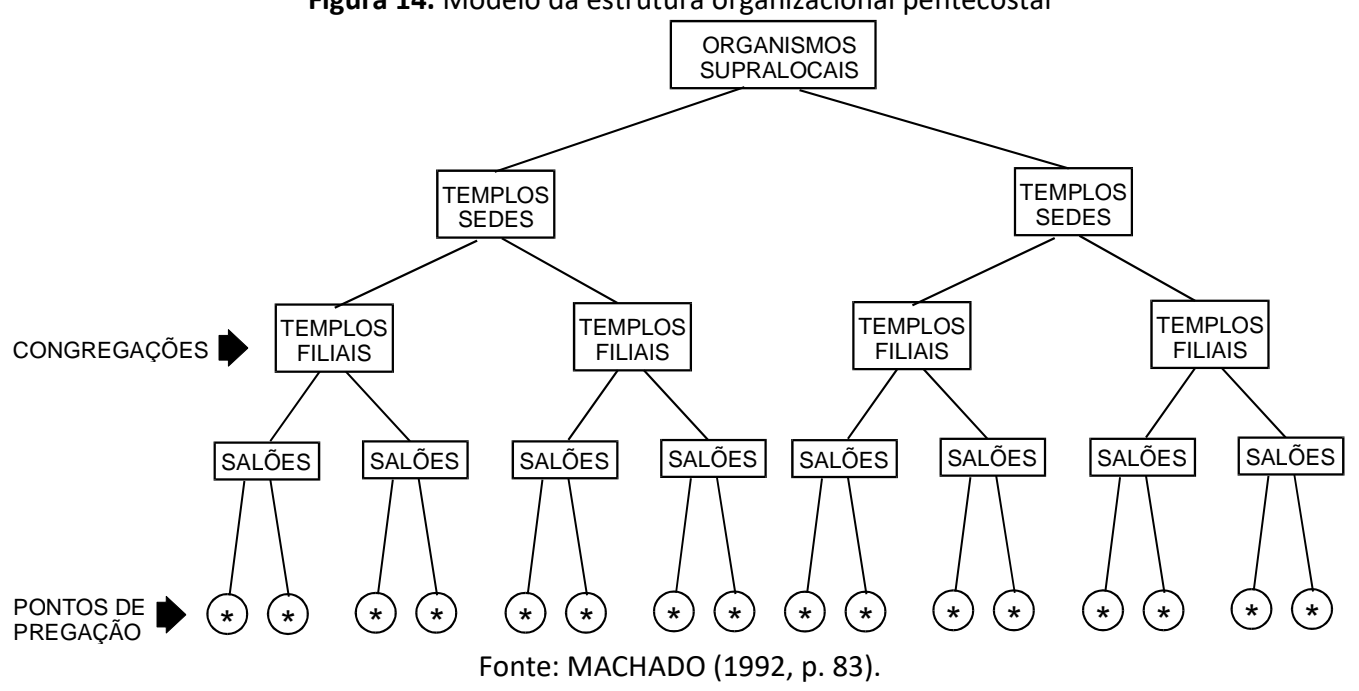

No caso específico da Universal, com base na análise dos dados disponíveis no site e no blog da própria Igreja e em matérias veiculadas em jornais, observa-se que a prática da nucleação espontânea e o envio de missionários, no Brasil e no exterior, são frequentes e constantemente monitorados pelas instâncias de gestão superior. Nos últimos dez anos a Universal ampliou e diversificou a prática de evangelização com missionários. Se antes a evangelização por envio de missionários se dava predominantemente em espaços públicos e junto às sociedades tradicionais, nota-se hoje um novo braço missionário, direcionado aos espaços institucionais, como presídios, casas socioeducativas, hospitais, etc., e aos agentes de segurança pública, como guardas municipais e estaduais, exército brasileiro e agentes penitenciários. Essa prática catequista chega também nesses ambientes pelas redes sociais.

Sobre a evangelização das forças policiais, estratégia que tem sido utilizada e valorizada pela Universal, uma pesquisa realizada pelo Fórum Brasileiro de Segurança Pública, em parceria com a Decode Pulse, empresa de inteligência de dados, publicada pela Revista Piauí, em 22 de setembro de 2020, apresenta resultados interessantes. Buscando avaliar o impacto da religião nas polícias militar e civil e na Polícia Federal, essa pesquisa investigou as interações dos perfis em ambientes públicos no Facebook e demonstrou forte associação no grupo evangélico pentecostal entre polícias, religião e política, o mesmo não se verificando nas outras denominações religiosas, que mantêm distância entre fé e política. Como pode ser observado no gráfico a seguir, $48 \%$ dos policiais civis, militares e federais que interagem publicamente em ambientes pentecostais concordam com as pautas defendidas pelo presidente Bolsonaro, sendo que $31 \%$ interagem em ambientes bolsonaristas radicais. Relação que não se verifica nos evangélicos tradicionais, católicos e espíritas. ${ }^{23}$

\footnotetext{
${ }^{23}$ https://piaui.folha.uol.com.br/biblia-e-bala.
} 
Figura 15. Interações em ambientes religiosos e políticos por policiais civis, militares e federais, 2020

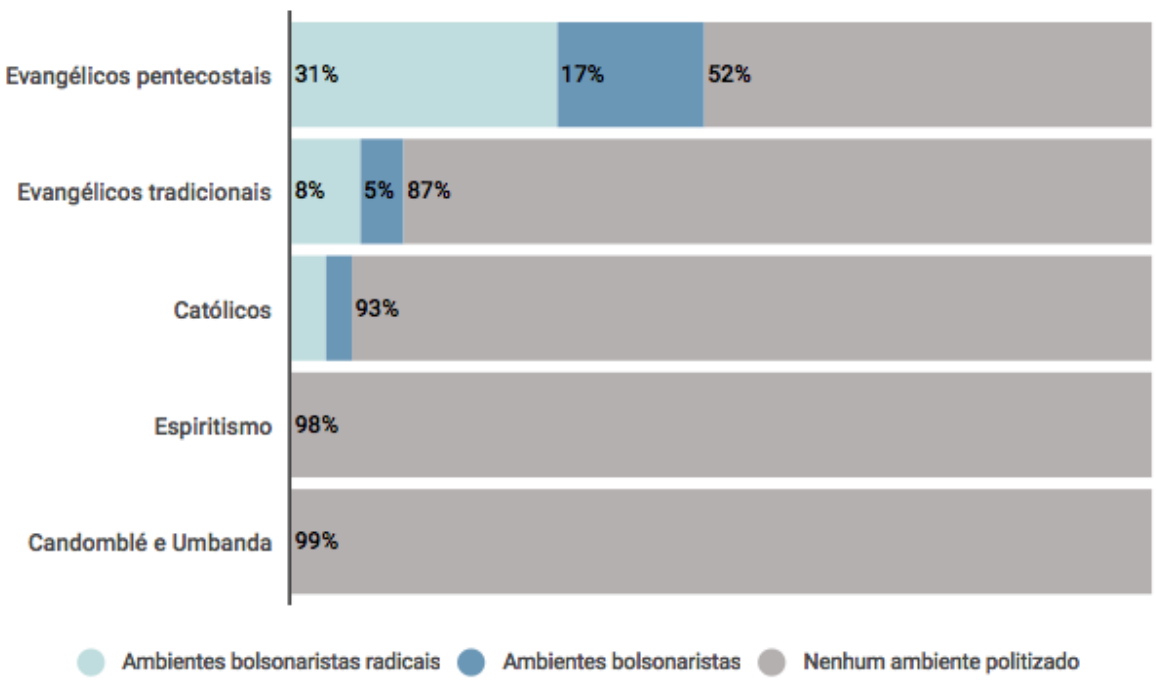

Fonte: Revista Piauí (https://infogram.com/politica-religiao-e-policia-1hdw2j3d9ydx6l0).

Outra característica pentecostal que favorece sua expansão é a não exigência de uma educação formal e acadêmica. A exemplo das igrejas pentecostais e neopentecostais, na Universal não há exigência de um clero letrado e formado academicamente que centralize todas as decisões, como na igreja católica e nas protestantes históricas, embora seja observado, de forma crescente, um clero decisório cada vez mais formado academicamente, sobretudo nas denominações pentecostais mais tradicionais, mais antigas. Apesar de haver um controle sobre os templos por parte das instâncias superiores de poder, sua difusão não depende diretamente das determinações dessas instâncias, mas do esforço individual de cada crente. Intimamente vinculada a esta descentralização há a orientação laica. Como se trata de uma religiosidade popular, a qualificação para ser um dirigente, um pastor, é a prática, o que importa é a habilidade empírica de evangelizar, e não a instrução formal e universitária. Não só os fiéis, mas também os pastores são "homens do povo". Eles constituem um grande exército leigo, lutando como soldados para difundir sua religiosidade. Assim, a estrutura organizacional da Universal permitiu a associação de estratégias territoriais originárias e novas, o que parece ter sido fundamental para o sucesso da expansão de sua mensagem religiosa, sustentada sobretudo na Teologia da Prosperidade.

Os dois esquemas a seguir sintetizam e ilustram, de um lado, o comportamento e a dinâmica espacial das igrejas históricas (protestantes e católica), e de outro, das igrejas pentecostais e neopentecostais. São dois diferentes modelos de ocupação espacial, isto é, de territorialidade e território. A peculiaridade do pentecostalismo, e da Universal, está na sua informalidade e espontaneidade, que tornam sua difusão espacial dinâmica e de fácil adaptação às inúmeras situações, desafios e impactos do capitalismo global. 
Figura 16. Modelos de ocupação espacial de igrejas históricas e pentecostais

Igrejas históricas (protestantes e católica)

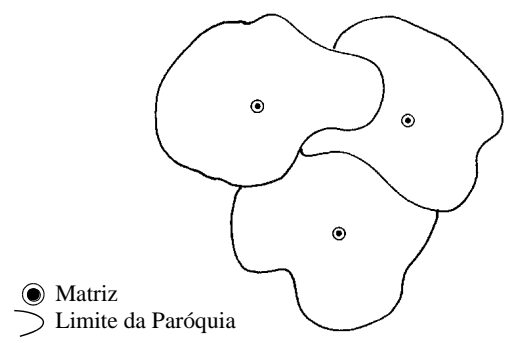

Igrejas pentecostais

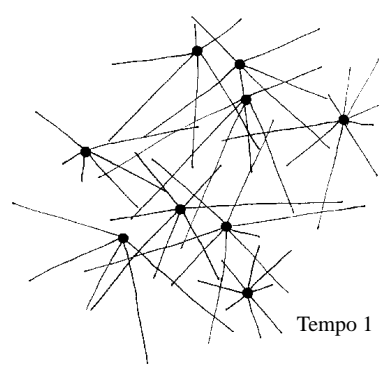

Tempo 1

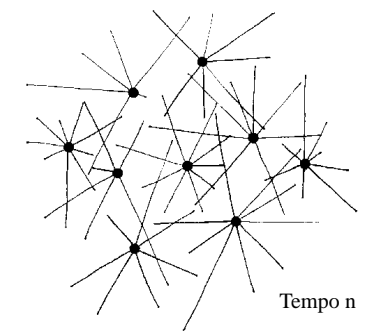

Fonte: MACHADO (1992, p. 162).

Assim, a lógica da estrutura organizacional das igrejas pentecostais, ao mesmo tempo rígida e flexível, hierárquica e espontânea, parece contribuir bastante para o sucesso de sua expansão. Nessa estrutura, as estratégias espaciais ocupam lugar importante, não apenas por incluírem as elaboradas e planejadas pelas instâncias de maior hierarquia da igreja, como também por permitirem a incorporação de ações individuais ou coletivas espontâneas, que surgem nos espaços cotidianos. Essa dinâmica não é exclusiva da Universal, é a dinâmica de todas as igrejas pentecostais e neopentecostais, justamente os segmentos protestantes que mais se difundem, não somente em território brasileiro. Nessas estratégias espaciais estão incluídas tanto ações verticais, de cima para baixo, como, por exemplo, construção de igrejas, envios de missionários, publicação de livros, edição de jornais impressos, criação de redes sociais, organização de programas e publicidades para veiculação em rádios, TVs abertas e fechadas, internet, etc., quanto ações de baixo para cima, ou seja, que surgem na base, de forma espontânea e difusa em diferentes lugares. Como o pentecostalismo é uma religiosidade popular, as ações verticais são direcionadas às populações mais pobres, que não por acaso habitam as áreas periféricas das cidades, como também são nesses espaços que as ações espontâneas, de base, mais emergem.

Conforme a Universal foi se expandindo territorialmente, não apenas foi ampliando os números de fiéis e a arrecadação de dízimos como também aprimorando e modernizando sua forma de gestão. Passou a se organizar com base em um moderno modelo empresarial, com centros decisórios de alcance global, conectados e articulados em redes, e a investir em empresas de diferentes segmentos. Tornou-se uma igreja com força econômica e política não apenas no país, mas também no exterior. Apesar de a Universal não ser a maior igreja pentecostal do Brasil em número de fiéis (tendo inclusive perdido adeptos, segundo dados dos últimos censos realizados pelo IBGE 2000 e 2010, possivelmente para a Assembleia de Deus, maior denominação pentecostal, com um total de fiéis seis vezes maior do que a Universal), ela conseguiu construir 
uma forte representação política no Congresso Nacional, sobretudo pelo partido Republicanos. Foi a segunda igreja que mais elegeu parlamentares nas últimas eleições, em 2014 e 2018.

De acordo com dados veiculados no site Congresso em Foco, 2018, no último pleito em 2018, dos 513 deputados federais eleitos, 91 são evangélicos, com predomínio dos pentecostais. No Senado foram eleitos 54 senadores, dos quais 9 são evangélicos: 5 da Assembleia de Deus; 2 da Batista; 1 da Nova Vida; e 1 da Luz dos Povos. ${ }^{24} \mathrm{O}$ grupo evangélico na Câmara dos Deputados ficou composto por várias denominações; três delas se destacam: a Assembleia de Deus, com 28 deputados, a Universal, com 17, e a Batista, com 10. Em seguida estão a Presbiteriana, com 5, o Evangelho Quadrangular, com 4, a Internacional da Graça de Deus, com 3, a Luterana, com 2, a Maranata, com 2, e as outras com um deputado cada uma, conforme pode ser observado no gráfico a seguir.

Figura 17. Deputados federais evangélicos eleitos em 2018

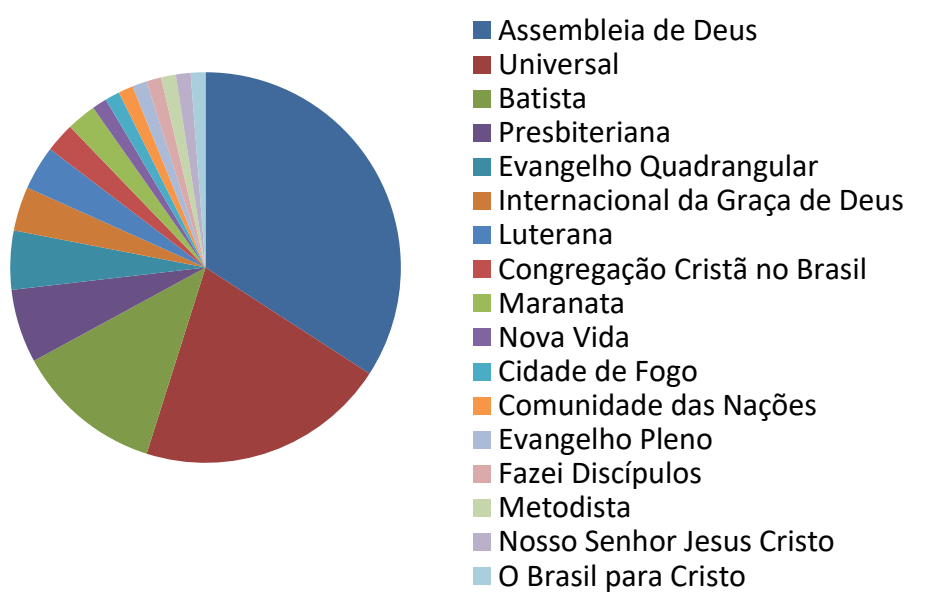

Fonte: https://congressoemfoco.uol.com.br/legislativo/renovada-bancada-evangelica-chega-com-mais-forca-no-proximo-congresso.

Embora a Universal não tenha elegido nenhum candidato para o Senado, na Câmara dos Deputados, proporcionalmente ao seu número de membros, ela teve uma representação bem mais expressiva do que a Assembleia de Deus, a igreja pentecostal com maior número de adeptos. A Universal, com cerca de 1.900.000 fiéis, elegeu 17 deputados federais, enquanto a Assembleia, com 12.350.000 de fiéis, elegeu 28. Vale salientar que todos os deputados federais da Universal eleitos em 2018 pertencem a um só partido, o Republicanos. ${ }^{25}$

\footnotetext{
${ }^{24}$ https://congressoemfoco.uol.com.br/legislativo/renovada-bancada-evangelica-chega-com-mais-forca-no-proximo-congresso.

25 https://congressoemfoco.uol.com.br/legislativo/renovada-bancada-evangelica-chega-com-mais-forca-no-proximo-congresso.
} 
Figura 18. Distribuição dos templos da Universal no Brasil, por regiões, 2020

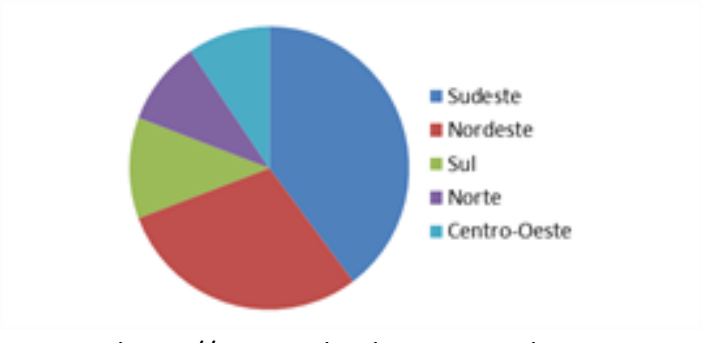

Fonte: https://universalenderecos.wordpress.com.

É interessante observar que a Universal construiu toda essa expressão a partir das camadas sociais mais pobres e de baixa escolaridade, as quais, em função do crescimento econômico de finais do século XX e início do XXI, com a globalização e a urbanização generalizada, foram não só sendo incorporadas ao mercado e ascendendo em termos de classes sociais como também estavam ávidas por consumo. A Teologia da Prosperidade foi, assim, absorvida com muita facilidade. A partir desse amplo segmento social, a Universal conseguiu transformar uma pequena denominação em uma poderosa holding evangélica, com investimentos em vários setores e empresas. Reuniu religião e empreendedorismo, fé e lógica empresarial, campo religioso e estratégia de mercado, expandindo no mundo inteiro não apenas a mensagem pentecostal, mas também rendimentos, arrecadação e investimentos. Forma de ação muito adaptável à dinâmica desse novo capitalismo, de matriz eminentemente americana.

\section{CONSIDERAÇÕES FINAIS}

Este texto resultou de um extenso processo de indagação e pesquisa sobre a expressão que os evangélicos pentecostais alcançaram, sobretudo nas últimas décadas, não apenas em números de fiéis, mas também econômica e politicamente. Em um curto período de tempo, várias pequenas denominações se tornaram grandes e poderosas igrejas, como foi o caso da Universal. Do ponto de vista econômico, em função de receber grande parte dos dízimos em dinheiro em espécie, principalmente durante os cultos, a identificação da direção dos investimentos da Universal é muito difícil. Contudo, seus templos e igrejas são indicativos importantes do montante de recursos que movimenta. Já do ponto de vista político, pela natureza dessa atividade, que exige registros formais dos políticos e sua divulgação pública, ficam evidentes tanto o aumento de sua força no legislativo e no executivo como suas atuações e pautas. Embora a proposta deste trabalho tenha se limitado a demonstrar o crescimento e o movimento de suas articulações políticas, e não de suas pautas e projetos de lei, não se pode deixar de assinalar o conservadorismo de seus conteúdos, sobretudo em virtude do atual quadro da política nacional brasileira. 
O crescimento evangélico, do qual a Universal faz parte, sendo um exemplo de sucesso religioso e político, tem sido o grande responsável pela transação religiosa brasileira e latino-americana na direção menos católica. $\mathrm{O}$ aumento da pluralidade religiosa e a expressão dos protestantes pentecostais e neopentecostais no continente estão associados à atual globalização aos moldes americanos, cuja urbanização generalizada é sua condição. Esse novo modelo capitalista e seu ambiente urbano se instauraram não apenas na América, mas em todo o mundo. Cada vez mais sistêmica e planetária, essa globalização passou tanto a criar quanto a exigir, igualmente, modernas formas de produção, de consumo e de comportamentos e expressões políticas, religiosas e culturais. É nesse novo ambiente e cenário que os evangélicos pentecostais passam a ampliar seu número de fiéis e de igrejas e a se expandir, territorial e politicamente. O que não ocorre por acaso, mas por uma grande interação e ajustamento de suas práticas religiosas e mundanas a esse novo ambiente, e aqui a Teologia da Prosperidade tem enorme participação. Essa interação e ajustamento são também verificados pela adoção dos pentecostais e neopentecostais de novas formas de gestão, em moldes empreendedores e empresariais, e de estratégias espaciais de difusão igualmente modernas e adaptáveis, conforme exemplificado pela atuação da Igreja Universal do Reino de Deus.

Nesse sentido, cabe aqui assinalar o papel da estrutura organizacional da Universal no sucesso de sua expansão, ao mesmo tempo rígida e flexível, hierárquica e espontânea, muito diferente da estrutura das igrejas protestantes históricas e da igreja católica. Nessa estrutura, as estratégias espaciais ocupam lugar importante, não apenas por incluírem as elaboradas e planejadas pelas instâncias de maior hierarquia da igreja, mas também por permitirem a incorporação de ações individuais ou coletivas espontâneas, que surgem nos espaços cotidianos. E, nessa direção, a Universal conjugou muito bem dinamismo espontâneo e práticas de gestão modernas, planejadas em rede. E mais, associou de forma exemplar fé e política.

\section{REFERÊNCIAS}

ALVES, José Eustáquio; Cavenaghi, Suzana; Barros, Luiz Felipe; Carvalho, Angelita A. de. Distribuição espacial da transição religiosa no Brasil. Tempo Social, São Paulo, v. 29, n. 2, p. 215-242, maio 2017. https://doi.org/10.11606/0103-2070.ts.2017.112180

CASTELLS, Manuel. A questão urbana. Rio de Janeiro: Paz e Terra, 1983.

DAVIS, Mike. Planeta favela. São Paulo: Boitempo, 2006.

LEFEBVRE, Henri. A revolução urbana. Belo Horizonte: UFMG, 1999.

LEMOS, Cristina; TAVOLARO, Douglas. O bispo: a história revelada de Edir Macedo. São Paulo: Larousse do Brasil, 2007.

IBGE, Censo Demográfico, 1980, 1991, 2000, 2010. (https://www.ibge.gov.br/estatisticas/sociais/populacao/25089-censo-19916.html?=\&t=o-que-e)

MACHADO, Mônica S. A Territorialidade Pentecostal: um estudo de caso em Niterói. Dissertação (Mestrado em Geografia). Programa de Pós-Graduação em Geografia, Universidade Federal do Rio de Janeiro, 1992.

MACAHDO, Mônica S. A lógica da reprodução pentecostal e sua expressão espacial. SANTOS, Milton et al. O novo mapa do mundo: fim de século e globalização. São Paulo: Hucitec, 1993. p. 224-232. 
MACHADO, Mônica S.; NACIF, Cristina Lontra. A representação político-territorial dos pentecostais no Rio de Janeiro: reflexões preliminares. In: CONGRESSO BRASILEIRO DOS GEÓGRAFOS, 6, 2004. Associação dos Geógrafos Brasileiros (AGB). Anais... Goiânia, 2004.

MACHADO, Mônica S.; NACIF, Cristina Lontra. Evangélicos, política e espaço: novas estratégias rumo à presidência da República? GeoUERJ, v. 2, p. 566-589, 2016. https://doi.org/10.12957/geouerj.2016.27012

MAFRA, Clara. Os evangélicos. Rio de Janeiro: Jorge Zahar, 2001.

MARIANO, Ricardo. Expansão pentecostal no Brasil: o caso da Igreja Universal. Estudos Avançados, São Paulo, v. 18, n. 52, p. 121138, 2004. http://dx.doi.org/10.1590/S0103-40142004000300010

NEXO JORNAL. 25 de setembro de 2017. https://www.nexojornal.com.br/interativo/2017/09/25/Compare-a-densidadepopulacional-das-cidades-neste-mapa-interativo.

NEXO JORNAL. 6 de novembro de 2017. https://www.nexojornal.com.br/grafico/2017/11/06/A-expans\%C3\%A3o-evang\%C3\%A9licano-Brasil-em-26-anos.

RIBEIRO, Ana Clara Torres. O poder (des)organizador dos meios de comunicação. In: PIQUET, R.; RIBEIRO, A. C. Brasil: território da desigualdade. Rio de Janeiro: Jorge Zahar, 1991. p. 44-55.

ROLIM, Francisco Cartaxo. Pentecostalismo no Brasil: uma interpretação sócio-espacial. Petrópolis: Vozes, 1985.

ORO, Ary P. A presença religiosa brasileira no exterior: o caso da Igreja Universal do Reino de Deus. Estudos Avançados, v. 18, n. 52, 2004, p. 139-155, 2004. https://www.scielo.br/pdf/ea/v18n52/a11v1852.pdf

PIAUÍ, Revista [online]. 21 de Setembro de 2020. https://piaui.folha.uol.com.br/dizimos-e-dividas.

PIAUÍ, Revista [online]. 22 de Setembro de 2020. https://piaui.folha.uol.com.br/biblia-e-bala.

SANTOS, Milton. Metamorfoses do espaço habitado. São Paulo: Hucitec, 1988.

SANTOS, Milton; SOUZA, Maria Aparecida de; SCARLATO, Francisco Capuano; ARROYO, Mônica (Orgs.). O novo mapa do mundo: fim de século e globalização. São Paulo: Hucitec, 1993a.

SANTOS, Milton. A urbanização brasileira. São Paulo: Hucitec, 1993b.

SANTOS, Milton. Técnica, espaço, tempo: globalização e meio técnico-científico informacional. São Paulo: Hucitec, 1994.

SANTOS, Milton. A natureza do espaço: técnica e tempo, razão e emoção. São Paulo: Hucitec, 1996. 